\title{
C. Clinical: \\ Mechanisms, Types and Treatment of Injuries
}

\section{NEW TECHNIQUE AND METHODS IN THE RESEARCH INTO SPORTS INJURIES}

\author{
Z. HORNOF, M.D. \\ Institute of Sports Medicine, Faculty of Medicine, Charles'University, PIzeñ \\ and \\ C. NAPRAVNIK, M.D. \\ Department of Sports Medicine, Faculty of Physical Education and Sports, \\ Charles'University, Prague, Czechoslovakia
}

\begin{abstract}
The authors, according to the determined method of division of causes and mechanism of sports injuries, have processed 12,782 sport injuries. When a computor was applied, a detailed observation of causes and mechanism of injuries in different kinds of sports and also their mutual interdependence was possible.

The causes of injuries were divided in subjective causes $(2.2 \%)$ and objective ones. These were further divided as objective themselves $(16.4 \%)$ caused by a factor of another person $(64.9 \%)$ by a technical factor $(8.8 \%)$ by climatic influences $(7.2 \%)$ on basis of wrong organisation $(0.0 \%)$ and unknown causes $(0.5 \%)$.

Mechanism of injuries was presented as a downfall (15.4\%) a downfall as a component of a sport action (12.3\%) a jump up $(1.1 \%)$ striking $(28.1 \%)$ a stroke $(11.6 \%)$ a collision $(26.8 \%)$ a sudden uncoordinated movement $(4.0 \%)$ different $(0.2 \%)$ and an unascertained mechanism $(0.5 \%)$.
\end{abstract}

On the basis of results achieved in this study the authors have developed new aspects on the prevention of sport injuries.

\section{Introduction}

During the last one hundred years the evolution of sports movement was being accompanied by various casuistic papers on sports injuries, which began to appear in the medical literature. The increasing number of athletes, as well as the increasing intensity of training, is reflected negatively in both the number and seriousness of the injuries. Thus in the beginning of the recent century we could have read various papers that have dealt with a comparison of the number of injuries as occurring in various sports disciplines. In the subsequent phase of sports injuries investigations, the frequency of injuries was being assessed according to the number of athletes and injuries. Finally, a more accurate evaluation of the risk of individual sports has brought about the requirement that the length of the particular time interval be taken into account, during which the athlete is exposed to the chance of an injury. However the recent methods of following sports injuries may have provided accurate information of the occurance of the same as well as of their medical nature, they have been but of a slight help to the actual injury prevention.

The application of epidemiological working methods to sports traumatology requires a multilateral analysis of both the causes and mechanisms of sports injuries. The detailed analysis ought to be carried out in large samples, which can be realised by means of the modern computing technique, if all the appropriate criteria be clearly defined and determined.

In various sports we do know the proper causes of injuries; however, we are not able to remove them without interfering with the very substance of the sport. Therefore we try and find the way of improvement by analyzing the mechanism of the injuries. The recognition of the same enables us to propose the appropriate prevention, so that even when the cause itself is not removed, appropriate protective equipment can avoid the injury.

\section{Methods and results}

In our investigations of the causes and mechanisms of injuries 12,782 injury records were analyzed. In Czechoslovakia all the sports unions have been unified, as far as their organization is concerned. In 1967 there were 1,441,795 athletes registered. The unified insurance of athletes brought about a financial reward for every injured athlete whose medical treatment lasted for more than 2 weeks. The question of the causes and 
mechanisms of injuries was given a special care.

According to their causes, the injuries were divided into six principal groups. The cause of injury will be defined as the phenomenon which closely preceded the injury. Thus we can ask "who" or "what" actually caused the injury. The sports injuries of our sample, divided according to various causes, are listed in Table 1.

Table 1

The causes of sports injuries in Czechoslovakia

The causes of injuries

Subjective causes

Objective causes

The factor of another person

Technical causes

Climatic causes

Organizatory causes

Unidentified causes

On the whole

The mechanisms of injuries were divided into eight principal groups. The mechanism of injury will be defined as the biophysical description of the injury phenomenon. This answers the question "how" the injury happened. The results showing the distribution of injuries according to various mechanisms are listed in Table 2.

Table 2

The mechanisms of sports injuries in Czechoslovakia

The injury mechanism

Fall

Deliberate fall

Jump-up

Stroke

Impact

Collision

Uncoordinated motion

Various mechanisms

Unidentified mechanisms

On the whole

\begin{tabular}{rr}
$\begin{array}{l}\text { Number of } \\
\text { injuries }\end{array}$ & \multicolumn{2}{l}{$\%$} \\
& \\
285 & 2.2 \\
2,091 & 16.4 \\
8,294 & 64.9 \\
1,125 & 8.8 \\
919 & 7.2 \\
7 & 0.0 \\
61 & 0.5 \\
12,782 & 100.0
\end{tabular}

Wrong training methods, wrong warming up, as well as incorrect performance of particular exercises, are included in the objective causes of injuries. The most frequent mechanism of injuries resulting from objective causes is the deliberate fall $(40 \%)$. This occurs mostly in gymnastics and volleyball. Another most frequent mechanism, appearing in the first place in lawn-tennis and the track-and-field disciplines, is a sudden and uncoordinated motion (18\%; Fig. 2).

FIG. 2

INJURIES FROM OBJECTIVE CAUSES, DIVIDED ACCORDING TO INJURY MECHANISMS (2,091 INJURIES)

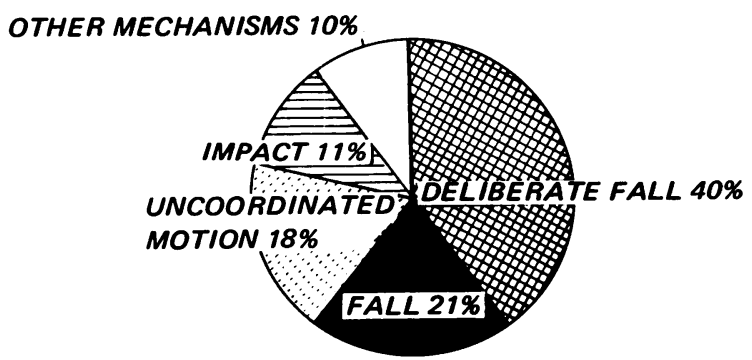

The most numerous group includes injuries caused by another person. In principle it is the rival who injures, may he do it intentionally or not. The most frequent mechanism of such an injury is either a stroke (42\%), occurring in the first place in ice-hockey, boxing. handball, or a collision $(41 \%)$ occurring mostly in UNCOORDINATED MOTION $15 \%$

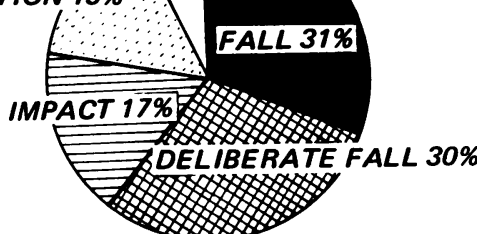

Special attention was paid to the relation between the

The psychical and physical qualities of a subject, inherited or attained, will be counted in the subjective causes of injuries. The most frequent mechanism of This mechanism of injury for subjective reasons will be observed mostly in horse riding (Fig. 1).

FIG. 1

INJURIES FROM SUBJECTIVE CAUSES, DIVIDED 
football, cycling and handball (Fig. 3).

FIG. 3

INJURIES CAUSED BY ANOTHER PERSON, DIVIDED ACCORDING TO INJURY MECHANISMS (8,294 INJURIES)

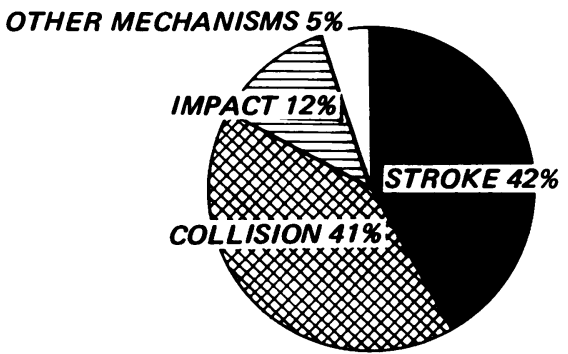

The technical causes of injuries are represented by various failures in the equipment, playground surface and playground apparatus. Here the most frequent mechanism of injury is the fall $(49 \%)$, occurring especially in horse riding, cycling and skiing. (Fig. 4).

FIG. 4

INJURIES FROM TECHNICAL CAUSES, DIVIDED ACCORDING TO INJURY MECHANISMS (1,125 INJURIES)

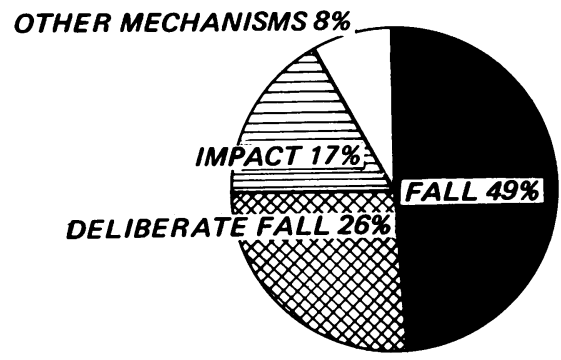

The climatic conditions, as another cause of injury, lead most frequently to the fall $(69 \%)$, which mechanism appears first of all in skiing. (Fig. 5).

FIG. 5

INJURIES FROM CLIMATIC CAUSES, DIVIDED ACCORDING TO INJURY MECHANISMS (919 INJURIES)

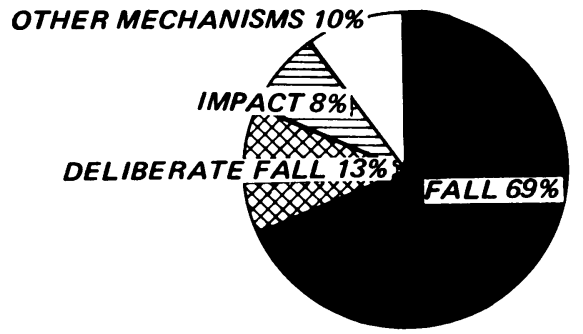

The last group, which is nearly negligible with its small number of cases, involves the organizatory causes of injury. The most frequent mechanism will be an impact.

\section{Discussion}

Our analysis of injuries resulting from subjective causes has shown that especially the horse riding and gymnastics requires a perfect psychological condition of the subject. Otherwise any distraction, hesitation or discomposure, however short it may be, can cause an injury whose mechanism will most frequently be a fall.

The deliberate fall, as the most frequent mechanism of injuries resulting fron objective causes, makes us aware of the fact that when training various elements of a sport, we have to be particular about the last phase of the motion, i.e. about the downfall and landing, especially in the track-and-field disciplines and volleyball. The injuries whose mechanism is an uncoordinated motion - appearing most frequently in lawn-tennis and track-and-field disciplines - ought to be avoided by a perfect preparation prior to every sports performance.

Our analysis of injuries caused by another person, as occurs most frequently in the collective sports, has shown that the injury mechanism will usually be a stroke, or a collision. The prevention consists, first of all, in strict keeping the rules. On the other hand, in order to avoid injuries that occur in accordance with the rules, it is necessary to use and continuously to improve appropriate protective equipments. Since we also meet intentional injuries, it is necessary to be particular about the moral education of athletes, a special responsibility borne by coaches and referees.

A considerable percentage of injuries resulting from technical causes and leading mostly to falls, points out to the necessity of taking greater care of the arrangement and upkeep of the surface of sports terrains and playgrounds.

The climatic conditions usually cause various kinds of falls, as well as injuries resulting from uncoordinated motions. The prevention requires sports shoes of quality appropriate to the terrain; we also have to respect eventual changes appearing due to the actual climatic conditions - especially in skiing.

We have mentioned that the modern computing technique can be used for a more detailed analysis of the relations between the causes and mechanisms of injuries. Similarly, we can use this technique for a comparison of various further aspects related with sports injuries. There are, for instance, the age and sex, the type and location of the injury, the kind of the actual sports activity, the seriousness of the injury, the social factors, etc. 


\title{
OBITUARY
}

\section{Doc. MUDr. Zdeněk Hornof, Csc.}

On 12th February, 1973 sports medicine in Czechoslovakia lost one of its founders and representatives, doc. MUDr. Zdenek Hornof, Csc. Being only 63 years of age, he died after a protracted and severe disease, having spent almost all the years of his life in unflagging work in which he displayed drive and initiative.

Since 1949 he was working as assistant at the Institute of Sports Medicine of the medical faculty, Charles University in Prague. In 1954 he moved to Plzen, where he became the head of the Department of Sports Medicine of the medical faculty. On 1st July 1963 he was appointed assistant professor and soon after gained the degree of Candidate of Sciences. In 1948 he was appointed Membre appele de la Federation Internationale de Medicine Sportive (FIMS).

The centre of interest of his scientific work lay, above all, in the prevention of injuries occurring in sporting activities, as well as in the problem of exercise physiology relating to the heart, and functional circulatory tests. $\mathrm{He}$ also published many studies from the sphere of the history of medicine. In the whole he published 144 studies, of which 91 were original scientific works from sports medicine, and 53 from the sphere of the history of medicine.

The life and work of Dr. Hornof will always be an example of a diligent, studious, tactful and good man for all those who were so lucky as to be his pupils and cooperators.

C. Nápravník

\section{TENDON INSERTION PATHOLOGY IN FIELD AND TRACK ATHLETES, ESPECIALLY IN JUMPERS, THROWERS AND RUNNERS.}

\author{
P. HEIDENSOHN, M.D.
}

"Orthopadische Klinik, 1 Berlin 33, Dahlem, Clayallee 229, Germany

* (Present address - unknown)

\section{ABSTRACT}

102 outstanding athletes were questioned about their injuries which may refer to stress-reactions in the insertions of their tendons. The duration, the treatment and the success of the treatment of their sufferings were also considered. The 102 athletes who were questioned were split up as follows:
a. 55 runners
b. 23 throwers
c. 12 jumpers
d. 13 decathletes

76 from 102 suffered from symptoms which may arise from lesions of tendon insertions.

In most cases, 96 out of 102, insertion-tendopathies were present in the lower limbs. The achillodynias pain in Achilles tendons were present in 29 out of 96 , followed by tendopathias of the tuber ischiadicum, (ischial tuberosities), of the patellar tendon and of the tibia. Insertion-tendopathies in the throwers were not so frequent in this study and were mostly observed as epicondylopathies of the humerus.

49 athletes had focal infections in the last two years, such as tonsillitis and dental granuloma or sinusitis for instance. 44 out of this group had insertion-tendopathies. This may underline the importance of focal infections for the development of tendopathies.

The achillodynias, the pain on the tibia and the epicondylopathia are often resistant to any treatment. 


\title{
AVULSION OF THE ISCHIAL TUBEROSITY - A RARE SPORTS INJURY
}

\author{
H. FRINGS, M.D.
}

Sports Medicine Institute, Munster University, Germany

\section{ABSTRACT}

From the world literature we could find only 57 cases of traumatic tears (detachment) of the tuber ossis ischii (Ischial Tuberosity) and we put them together in table 1. The author (1970) adds to these 57 cases his own two; a 17 year old man, who got this rare injury in long jumping, - and a 20 year old sportsman, who got it while playing football. Both these (the authors own) cases were treated conservatively, as were most of the others.

Practically they are only sports injuries in the case of 52 men and 5 girls. ( 1 n two cases there was no mention of the sex). The left side was predominant as in most right-handed sportsmen the jumping leg is usually the left. ( 27 cases were on the left side, 22 cases on the right). In 10 cases we could not ascertain upon which side of the body the injury occurred. In most cases (37) the conservative treatment proved to be successful. Surgical treatment was performed in 14 cases. In 8 reported cases the author could not find a record of any therapy.

Only one recurrence was found (Cords, $H$. (1935)), who was as a matter of interest the German Decathlon - World Record holder (1934) H. H. Sievert (Hamburg). We only found one bilateral case (Gutschank, A. 1933) and only one in male twins (De Palma and Silberstein (1965))

In my opinion this sports injury happens more frequently, because many - for example, because of tear of the flexion musculature of the thigh - are not recognised and therefore no radiological examinations are done.

Any suspicion of such a sports injury should be clarified radio-diagnostically. The age range of the cases collected by the author - as far as the age was known for certain - is in the male from 8-27 years and in the female from 11-14 years, in which the younger ones are especially out numbering the older ones.

Table 1

No. Author

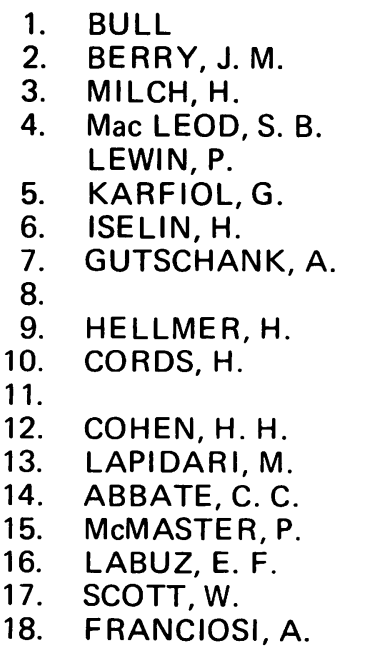

\begin{tabular}{|c|c|c|c|c|}
\hline $\begin{array}{l}\text { Year in } \\
\text { which } \\
\text { reported }\end{array}$ & Age & Sex & Side & Event \\
\hline $\begin{array}{l}1910 \\
1912 \\
1926 \\
1929\end{array}$ & $\begin{array}{l}- \\
23 \\
11 \\
17\end{array}$ & $\begin{array}{l}m \\
m \\
m\end{array}$ & $\begin{array}{l}\text { right } \\
\text { left } \\
\text { right } \\
\text { right }\end{array}$ & $\begin{array}{l}50 \text { kg "Snatch" } \\
\text { Sprint } \\
\text { Spagat Splits } \\
\text { High Jump }\end{array}$ \\
\hline $\begin{array}{l}1930 \\
1930 \\
1933\end{array}$ & $\begin{array}{l}19 \\
15 \\
17\end{array}$ & $\begin{array}{l}m \\
m \\
m\end{array}$ & $\begin{array}{l}\text { left } \\
\text { left } \\
\text { Bilateral }\end{array}$ & $\begin{array}{l}\text { Football } \\
\text { Prof. Running } \\
\text { Running }\end{array}$ \\
\hline $\begin{array}{l}1934 \\
1935\end{array}$ & $\begin{array}{l}16 \\
22 / 24 \\
\text { Recurrer }\end{array}$ & $\begin{array}{c}m \\
m\end{array}$ & $\begin{array}{l}\text { left } \\
\text { right }\end{array}$ & $\begin{array}{l}\text { 100-m-Run } \\
\text { High Jump }\end{array}$ \\
\hline $\begin{array}{l}1937 \\
1937 \\
1945 \\
1945 \\
1946 \\
1946 \\
1947\end{array}$ & $\begin{array}{l}15 \\
17 \\
16 \\
14 \\
16 \\
15 \\
14\end{array}$ & $\begin{array}{l}m \\
m \\
m \\
m \\
m \\
m\end{array}$ & $\begin{array}{l}\text { left } \\
\text { right } \\
\text { left } \\
\text { left } \\
\text { left } \\
\text { left } \\
-\end{array}$ & $\begin{array}{l}\text { Football } \\
\text { Jumping } \\
\text { Prof. Running } \\
\text { Long Jump } \\
\text { Football } \\
\text { Baseball } \\
\text { - }\end{array}$ \\
\hline
\end{tabular}

Treatment

Treatment

Conservative Operation Conservative Operation

Operation Conservative Conservative

Operation Conservative

Conservative Operation Conservative Conservative Conservative Conservative 
19. WINKLER, H

20. MOONEY, $V$.

21. CASTELLANA, A.

22. CASACCI, A.

23. CASTELLANA, A.

24. SCHEGGI, S.

25. CARNEVALE, $V$.

26. WARDLE, E. N.

27. De LUCCHI, G.

28. VACIRCA, M.

29. RINONAPOLI, E.

30. SCHNEIDER, G.

31. SCHNEIDER, G.

32. STAYTON, C. A.

33. STAYTON, C. A.

34. GOULD, N.

35. HAMSA, W. R.

36. MARTIN, T. A. PIPKIN, G.

37. MARTIN, T.A. PIPKIN, G.

38. MARTIN, T. A PIPKIN, G.

39. MINERVINI, G. L. CARUSO, A. M.

40. VOSTAL, $O$.

41. CAPPELLINI, 0. et al.

42. BARIGAZZI, P. D. 1965

43. De PALMA, A. F. 1965 SILBERSTEIN, Ch. E.

44. De PALMA, A. F. SILBERSTEIN, Ch. E.

45. JONASCH, E.

46. HOWARD, F.M. PIHA, R. J.

47. HOWARD, F.M. 1965

PIHA, R. J.

48. LUSCHNITZ, E. 1966

BEYER, W.

49. ELLIS, R.

GREENE, A. G.

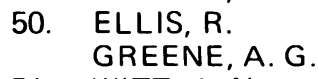

51. WITT, A. N.

52. ROICK, $\mathrm{H}$.

STRÖHMANN, G.

53. HOFEREITER, F.

54. KRESSIN, W.

55. KRESSIN, W.

56. WUSCHECH, H. et al.

57. FRINGS, $\mathrm{H}$.

58. FRINGS, $H$.

59. DUSI, E.

\section{7}

1947

1948

1949

1950

$1950 / 51$

1951

$1952 / 53$

1954

1954

1955

1956

1956

1956

1956

1957

1957

1957

1957

1957

1957

1957

1959

1965

1965

1965

1966

1966

1967

1968

1968

1968

1968

1969

1970

1970

1935
14

m

left

$15 \mathrm{~m}$ right

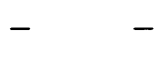

12

15

14

15

16

15

15

16

13

17

13

child $\mathrm{m}$

19

14

16

16

17

17

20 m

m

m

m

m

m

m

$\mathrm{m}$

m

m

$m$

$\mathrm{m}$

m

$\mathrm{m}$

$m$

$m$

$m$

m

$m$ right

left

left

right

right

left

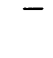

left

left

left

left

right

right

left

right

left

right

$-$

right

left

right

left

right

left

right
Long Jump

Football

Sports Injury

Football

Football

-

Horse Riding

Long Jump

Sports Injury

100-m-Sprint

300-m-Sprint

Long Jump

Horse Riding

Football

Hurdling

Gymnastics

Running

Long Jump

Operation

Conservative

Conservative

Conservative

Conservative

-

Operation

Conservative

-

Conservative

Conservative

Conservative

Conservative

Operation

Conservative

Conservative

Operation

Operation

Weight Training

Downhill Skiing

200-y-Run

Football

100-m-Run

Volleyball

Basketball

Football

75-m-Sprint

220-y-Sprint

Ski Jumping

Handball

High Jump

100-m-Sprint Start

High Jump

Athletics - Jumping

with sandbag

Long Jump

Football

Crash in "Herring.

Bone" Ski Run 


\section{REFERENCES}

1. ABBATE, C. C. Avulsion fracture of ischial tuberosity. A case report. J. Bone Jt. Surg. 27, $716-717$ (1945)

2. BARIGAZZI, P. D. Eccezionale associazione traumatica: distacco del piccolo trocantere e della tuberositâ ischiatica. Minerva ortop. 16, 266-267 (1965)

3. BERRY, J. M. Fracture of the tuberosity of the ischium due to muscular action. J. Amer. med. Ass. 59, 1450 (1912)

4. BLOUNT, W. P. Fractures in Children. pp. 204-205, Baltimore, Williams and Wilkins (1954)

5. BULL, Fractura tuberis ischii durch Muskelkontraktion. Norsk Mag. Laegevidensk. 5, 12 (1910)

6. CAMP, J. D., CILLEY, E. I. L. Diagrammatic Chart Showing Time of Appearance of Various Centers of Ossification and Period of Union. Amer. J. Roentgen 26, 905 (1931)

7. CAPPELLINI, O., LORENZI, G. L., PARENTI, G. Le fratture marginali del cingolo pelvico. Chir. Organi. Mov. 47, $177-195$ (1959)

8. CARNEVALE, V. Apofisiolisis del isquion. Bol. Soc. Argent. Ortop. y Traum. 16, 234 (1951)

9. CASACCI, A. Fratture da strappamento nell'adolescenza. Clin. Ortop. (Padova) 1, 163 (1949)

10. CAStellanA, A. Les apophysiolyses de l'ischion. Rev. Orthop. Chir. 34, 145-155 (1948)

11. CAStellanA, A. Su di un caso di apofisiolisi dell'ischio. Arch. Ortop. (Milano) 63, 417-423 (1950)

12. CAVE, E. F. Fractures and Other Injuries. Year Book Publishers (Chicago), p. 418 (1958)

13. COHEN, H. H. Avulsion fracture of the ischial tuberosity. J. Bone Jt. Surg. 19, 1138-1140 (1937)

14. CORDS, H. Frakturen durch Muskelzug beim Sport. Arch. Orthop. Unfall-Chir. 35, 563-585 (1935)

15. De LUCCHI, G. Distacco apifisario della tuberosità ischiatica. Clin, Ortop. (Padova) 6, 245 (1954)

16. De PALMA, A. F., SILBERSTEIN, Ch. E. Avulsion Fracture of the Ischial Tuberosity in Siblings. A Report of 2 Cases. Clin. Orthop. 38, 120-122 (1965)

17. DUSI, E. Sul meccanismo delle lesioni da sci. Atti del Congresso d. Medicino dello Sport, Mantova 1935

18. ELLIS, R., GREENE, A. G. Ischial Apophysiolysis. Radiology 87, 646-648 (1966)

19. FRANCIOSI, A. Raro caso di distacco del nucleo di ossificazione della tuberosità ischiatica. Ann. Radiol. Diagn. (Bologna) 19, 63-68 (1947)

20. FRINGS, H. Ober 88 subcutane Achillessehnenrupturen beim Sport. Mschr. Unfallheilk. 64, 325-329 (1961)

21. FRINGS, H. Sportärztliche Unfallambulanz der Universităt Münster 1950-1960. Sportarzt li. Sportmed. 12, 81-90 u. $122-132$ (1961)

22. FRINGS, H. Über 317 Fälle von operierten subcutanen Achillessehnenrupturen bei Sportlern und Sportleririnen. Arch. orthop. Unfall-Chir. 67, 64-72 (1969)

23. GIANOTTI, M. Chirurgia dello Sport. U.T.E.T., Torino 1939

24. GOULD, N. Avulsion fracture of the tuberosity of the ischium. Report of a case. New Engl. J. Med. 256, 747-748 (1957) 
25. GRAZIATI, G. II distacco della tuberositæ ischiatica. Clin. Ortop. (Padova) 12, 79 (1960)

26. GUTSCHANK, A. Doppelseitige Abrißfraktur der Tuber ossis ischii. Arch. orthop. Unfall-Chir. 33, $256-259$ (1933)

27. HAMSA, W. R. Epiphysial Injuries About Hip Joint. Clin. Orthop. 10, 119-124 (1957)

28. HELLMER, H. Ein Fall von traumatischer Ablösung der Ephiphyse des Os ischii. Arch. orthop. Unfall-Chir. 34, 45-47 (1934)

29. HELLNER, H. Die Knochengeschwulste. Springer Verlag, Berlin-Göttingen- Heidelberg 1950, 2. Aufl.

30. HOFEREITER, F. Pathologische Veränderungen der Sitzbeinapophyse. Med. Diss. Humboldt-Univ. Berlin, 1965

31. HOFEREITER, F. Zur Ätio-Pathogenese der Sitzbeintuber-Osteochondropathie und -Apophyseolyse. Radiol. diagn. (Berl.) 9, 621-631 (1968)

32. HOWARD, F. M., PIHA, R. J. Fractures of the apophyses in adolescent athletes. J. Amer. med. Ass. 192, 842-844 (1965)

33. ISELIN, H. Von den Beziehungen zwischen Geschwulstbildung und akzidentellem Trauma. Schweiz. med. Wschr. 60, $141-148$ u. 165 (1930)

34. JONASCH, E. Traumatische Lösung der Epiphyse des Os ischii. Mschr. Unfallheilk. 68, 288-290 (1965)

35. KARFIOL, G. Abrißfraktur des Tuber ischiadicum, Sportverletzung. Zbl. Chir. 57, 2466-2467 (1930)

36. KNÖDGEN, H. Über Beckenabrißfrakturen. Med. Diss., Berlin 1937, S. 17

37. KRESSIN, W. Apophysenlösung und Tumor am Os ischii in der Differentialdiagnose der Beugerzerrung an derō Oberschenkelrückseite. Med. u. Sport (Berl.) 8, 93-95 (1968)

38. LABUZ, E. F. Avulsion of the ischial tuberosity. Report of a case. J. Bone Jt. Surg. 28, 388-389 (1946)

39. LAPIDARI, M. Un raro caso di distacco traumatico del nucleo di ossificazione della tuberosita ischiatica. Accad. med. lombarda 5, 2019-2026 (1937)

40. McLAUGHLIN, H. Trauma. Philadelphia, pp. 478-479, W. B. Saunders (1959)

41. LUSCHNITZ, E., BEYER, W. Die seltene traumatische Epiphysenlösung am Os ischii. Fortschr. Röntgenstr. 105, 589-590 (1966)

42. MacLEOD, S. B., LEWIN, P. Avulsion of the epiphysis of the tuberosity of ischium. J. Amer. med. Ass. 92, 1597 (1929)

43. MAGNUSSON, R. Tuberculous Osteitis of the Ischium. J. Bone Jt. Surg. 20, 23-34 (1938)

44. MALAGAIGNE, J. F. Die Knochenbrüche und Verrenkungen. Deutsch bearbeitet von C. G. Burger, Stuttgart, Riegersche Verlagsbuchhandlung 1850

45. MARTIN, T. A., PIPKIN, G. Treatment of avulsion of the ischial tuberosity. Clin. Orthop. 10, 108-118 (1957)

46. McMASTER, P. Epiphysitis of the ischial tuberosity. A case report. J. Bone Jt. Surg. 27, $493-495$ (1945)

47. MAYDL, K. Über subcutane Muskel- und Sehnenzerreißungen, sowie Rissfracturen, mit Berücksichtigung der analogen, durch directe Gewalt enstandenen und offenen Verletzungen. Dtsch. Z. Chir. 17, 306 u. 513 (1882) Dtsch. Z. Chir. 18, 50-97 (1883)

48. MILCH, H. Avulsion fracture of the tuberosity of the ischium. J. Bone Jt. Surg. 8, 832-838 (1926) 
49. MILCH, H. Partial Resection of the Ischium. The operative procedure. J. Bone Jt. Surg. 17, 166-177 (1935)

50. MILCH, H. Tuberculosis of the ischial tuberosity: partial resection of ischium. Bull. Hosp. Jt. Dis. (N.Y.) 1, 9-13 (1940)

51. MILCH, H. Ischial apophysiolyses: a new syndrome. Clin. Orthop. 2, 184-193 (1953)

52. MILCH, H. Ischial apophysiolysis: a new syndrome. Bull. Hosp. Jt. Dis. (N. Y.) 14, 188-193 (1953)

53. MINERVINI, G. L., CARUSO, A. M. I distacchi apofisari osservati all'Istituto Ortopedico Toscano dal 1923 als 1956. Atti XL// Congresso S.I.O.T., Roma, 29-31, ottobre 1957

54. MOONEY, V. Avulsion fracture of tuberosity of ischium. Penn. Med. J. 50, 1072-1073 (1947)

55. O'DONOGHUE, D. Treatment of Injuries to Athletes. Philadelphia, W. B. Saunders, pp. $402-407$ (1962)

56. PIRKER, H. Die Verletzungen durch Muskelzug Ergebn. Chir. Orthop. 27, 553-634 (1934)

57. PIRKER, H., WUNDERLICH, H. Chirurgisch-orthopãdische Sportambulanz. Johann Ambrosius Barth Verlag, Leipzig 1939, S. 123-124

58. RAMPOLDI, A. BONI, M. I distacchi epifisari traumatici. Relaz. al XLI/ Congresso S.I.O.T., Roma 29-31. ottobre 1957

59. RINONAPOLI, E. Distacchi apofisari da trauma sportivo. Clin. Ortop. (Padova) 7, 337 (1955)

60. ROGGE, E. A. Avulsion of the ischial apophysis. Clin. Orthop. 9, 239 (1957)

61. ROICK, H., STRÖHMANN, G. Traumatische Lösung der Tuberapophyse am Os ischii Arch. orthop. Unfall-Chir. 64, 47-51 (1968)

62. von SAAR, G. Die Sportverletzungen. Neue deutsche Chirurgie 13, S. 58 (1914) F. Enke Verlag, Stuttgart

63. SCHEGGI, S. Frattura da strappamento della tuberosa ischiatica per trauma sportivo. Chir. Organi. Mov. 35, 736-739 (1951)

64. SCHNEIDER, G. Über isolierte Frakturen des Sitzbeines und Apophysenlösungen am Tuber ossis ischii. Arch. orthop Unfall-Chir. 48, 326-339 (1956)

65. SCOTT, W. None-union of the ischial tuberosity associated with epiphysitis vertebrae. Report of a case. J. Bone Jt. Surg. 28, 862-864 (1946)

66. STAYTON, C. A. Ischial Apophysiolysis. Amer. J. Roentgenol. 76, 1161-1162 (1956)

67. SULLIVAN, C. R. Fractures of Pelvis. Instruct. Lect. Amer. Acad. Orthop. Surg. 18, 92-101 (1961)

68. TEICHERT, G. Über Ossifikationsvarianten und Ossifikationsstorrungen am Tuber ossis ischii. Arch. orthop Unfall-Chir. 49, 169-176 (1957/58)

69. VACIRCA, M. Frattura da strappamento a sede rara in adolescenti sportivi. Minerva Chir. 9, 89-97 (1954)

70. VOSTAL, O. Odtrzeni hrbolu kosti sedaci u atletu. Acta Chir. orthop. Traum. cech. 24, 38 (1957)

71. WARDLE, E. N. Apophysitis of the Tuber ischii. Brit. J. Surg. 40, 180-181 (1952/53)

72. WATSON-JONES, R. Fractures and Joint Injuries vol. 2, ed. 4, p. 935, Baltimore, Williams and Wilkins (1952) 
73. WILLIAMS, J. P. G. Sports Medicine, Chapter 14: Injuries of the Lower Limb, p. 265-267; Ed. Arnold LTD., London 1962, p. 265-316

74. WINKLER, H., RAPP, I. H. Ununited epiphysis of ischium. Report of a case. J. Bone Jt. Surg. 29, $234-236$ (1947)

75. WITT, A. N. Klinik und operative Behandlung der Sehnenzerreißungen. Verh. Dtsch. Ges. Unfallheilk., XXX. Tagg., Frankfurt/Main 1966. H. z. Unfallheilk. 91, 262-272 (1967) Springer Verlag Berlin-New York.

76. WUSCHECH, H., LEHNIGK, P., AHRENDT, E. Seltene Sportverletzungen bei jugendlichen Sportlern. Med. $u$. Sport (Berl.) 9, 186-188 (1969)

ORAL ENZYME THERAPY IN INJURIES TO MUSCLE TENDONS AND BONES AFTER ACCIDENTS

O. SCHWINGER, M.D.

Surgical Dept., Kaiser Frarız Josef Hospital, Vienna.

\title{
ABSTRACT
}

On the basis of this trial carried out on injuries of the bones, tendons and muscles, the use of Chymoral produced distinct advantages in the rapid decrease of swelling and consequently a more rapid recovery and reduction of pain. Oral enzyme therapy can, therefore, demonstrate advantages in the treatment of accident injuries.

\author{
APPLICATION OF DIAPULSE THERAPY TO SPORTS TRAUMA \\ J. ROSS, M.D. \\ 4 Nevada Drive, Lake Success, New Hyde Park, New York, 11040
}

\begin{abstract}
The introduction of any trauma creates certain electrical changes within cells. This process was reviewed, and recent research described which indicates the ability of Diapulse therapy to accelerate the recovery time of these injuries by as much as $\mathbf{5 0 \%}$. The relief from pain, oedema, and acchymoses as well as the acceleration of the absorption of haematomas will also be reviewed and discussed. Many studies have been completed on fracture healing and wound healing at institutes all over the world.

Further theoretical and clinical aspects were presented during the Congress in the exhibition section.
\end{abstract}


THE USE OF CHYMORAL TABLETS IN ACCIDENT AND CASUALTY DEPARTMENTS

V. K. GOEL, M.S., F.A.C.S., DOMS., and Barun SENGUPTA, F.R.C.S.

Portland Hospital, Dorset

\begin{abstract}
Over a period of 8 months and involving 156 cases with accidental injuries of various types, it was possible to show that the use of proteolytic enzymes, as in the product Chymoral will reduce the recovery time considerably. Although it is appreciated that the cost of the tablets is comparatively high, the early recovery appears to be well worth their use by reducing the cost to the State, but more important, by reducing the disability of the patients concerned. It must also be appreciated that sporting personalities suffer financially, and their teams become less efficient if key players are incapacitated for long periods.
\end{abstract}

\title{
THE USE OF CHYMORAL TABLETS IN ACCIDENT AND CASUALTY DEPARTMENTS
}

\author{
V. K. GOEL, M.S., F.A.C.S., DOMS. and *B. SENGUPTA, F.R.C.S., Orthopaedic Dept. \\ *Present address - Poplar Hospital, East India Dock Road, London, E.14
}

Portland Hospital, Dorset

The accident and emergency departments of hospitals are usually crowded with patients who have suffered injuries ranging from minor cuts, bruises and lacerations, to major injuries requiring surgical intervention, including fractures. These injuries are similar to those occurring in sporting events.

A high percentage of these cases tend to prolong their visits to the casualty department unnecessarily, which increases the work load on casualty officers and is a financial embarrassment to the state. In professional sport, injury can be an embarrassment to management and a serious loss to the efficiency of a team. One must also bear in mind that professional sporting personalities suffer financial loss if they are incapacitated for long periods of time.

The efficiency of a casualty officer depends on the prompt measures and effective choice of treatment which contributes to the speedier recovery rate of the patients attending the casualty department, reducing the pressure of work.

In the past proteolytic enzymes, as in the product Chymoral, have been used in accidental injuries and various types of surgery. Blonstein ${ }^{1}$ in a double-blind trial showed that he could reduce the recovery time in haematomas, cuts and abrasions. Further evidence was provided by Boyne ${ }^{2}$ who compared favourably the results on the use of Chymoral in professional footballers in two successive seasons. Further clinical evidence by Lie and Larsen ${ }^{3}$ showed that the use of proteolytic enzymes would reduce the recovery rate by $50 \%$ in surgery associated with injuries to the hands. P. C. Shaw ${ }^{4}$ also conducted a double-blind trial involving 100 consecutive patients with injuries to the fingers where again the effectiveness of Chymoral was shown in increased mobility. The difficulties in assessing the use of proteolytic enzymes lies in the fact that it is virtually impossible to accumulate a series of identical injuries to produce a comparative trial.

The purpose of this article is to present the results achieved from the use of Chymoral as a supplementary therapy in a series of injuries, reporting to a casualty department, similar to those received by professional sporting personnel.

\section{Material and Methods}

The present study includes patients attending the casualty department of a major hospital in Dorset, reporting with the following types of injuries:-

\section{Bruises}

\section{Lacerations}

3. Haematomas

4. Haematomas associated with sprains and strains

A total number of 156 patients reporting to the casualty department were incorporated in the trial. The 
cases were divided at random into two groups and alternate patients were given Chymoral, together with emergency treatment, the remaining patients being treated with normal emergency treatment only.

$$
\begin{aligned}
& \text { Group 'A' - with Chymoral } \\
& \text { Group 'B' - without Chymoral }
\end{aligned}
$$

Patients reporting to the casualty department were checked for injuries to the bone involving fractures, these cases being automatically excluded from the trial. Patients suffering from systemic illnesses such as diabetes or hypertension, or who were on specific therapy, steroids or antimetabolic drugs were also excluded from the trial.

The patients were followed up at regular intervals either twice weekly or once weekly, and an accurate record was maintained of their progress.

\section{Results}

The patients' ages ranged from 14-45 years and 79 cases were treated with Chymoral, and 77 cases had normal routine treatment. The Chymoral tablets were administered at the recommended dosage pattern of 2 tablets 4 times a day, half an hour before meals, for a period of 7 days.

\section{TABLE}

\section{DISTRIBUTION OF CASES}

$\begin{array}{lll}\text { Painful } & \text { Badly } & \\ \text { Bruises } & \text { Lacerated Haematomas Sprains Total } \\ \text { Wounds } & \text { Wounds }\end{array}$

$\begin{array}{llllll}\text { GROUP 'A' } & 20 & 10 & 15 & 34 & 79 \\ \text { GROUP 'B' } & 20 & 10 & 15 & 32 & 77\end{array}$

\section{Discussion}

The use of Chymoral in the cases treated showed quite encouraging results. Cases of bruising from various causes showed a reduction in the time of recovery from 12 to 8 days, as compared with the control cases who did not recover, in some cases, until 4 weeks. Lacerated wounds under normal circumstances show irregular scarring in spite of adequate stitching technique and care. When Chymoral was used in these cases in addition to routine treatment, the results were very satisfactory.

Haematomas particularly of the forehead and the knee, usually take two to three weeks to resolve. When these cases were given Chymoral they were cleared in $\mathbf{1 0}$ to 12 days.
TABLE \|

\section{COMPARATIVE RESULTS IN PAINFUL BRUISES}

\begin{tabular}{lllll} 
& \multicolumn{2}{c}{ GROUP 'A' } & GROUP 'B' \\
$\begin{array}{l}\text { No. of } \\
\text { Injuries }\end{array}$ & $\begin{array}{l}\text { Time Taken } \\
\text { to Clear }\end{array}$ & $\begin{array}{l}\text { No. of } \\
\text { Cases }\end{array}$ & $\begin{array}{l}\text { Time Taken } \\
\text { to Clear }\end{array}$ \\
$\begin{array}{l}\text { Multiple bruises on } \\
\text { face and forehead }\end{array}$ & 6 & $8-12$ days & 6 & $10-15$ days \\
$\begin{array}{l}\text { Multiple bruises } \\
\text { face, injury to nose }\end{array}$ & 10 & 8 days & 10 & 15 days \\
$\begin{array}{l}\text { Assault - multiple } \\
\text { facial bruises with } \\
\text { black eyes }\end{array}$ & 2 & $10-12$ days & 2 & 20 days \\
$\begin{array}{l}\text { Crush soft tissue } \\
\text { injury to thigh with } \\
\text { toe wounds and } \\
\text { bruise on arm }\end{array}$ & 2 & 12 days & 2 & 4 weeks \\
\hline
\end{tabular}$$
\mathbf{P}=<0.02
$$

TABLE III

COMPARATIVE RESULTS BADLY LACERATED WOUND - 10

$$
\text { GROUP 'A' GROUP 'B' }
$$

Injuries

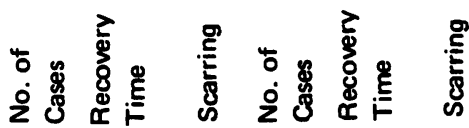

$$
\begin{aligned}
& \text { Multiple cut injuries to } 77 \text { days }++(3) 57 \text { days }++ \\
& \text { face } \\
& +(4)
\end{aligned}
$$

Sprains of the ankles are extremely common and restrict the patient seriously in all professional and social pursuits. Patients suffering from these types of injuries, where bone complications are excluded, usually take 2 to 3 weeks to clear. When Chymoral was used the average resolution was 7 to 12 days. It is noticeable that in accidental injury there was relief of pain within 24 hours and a considerable reduction of inflammatory oedema after a period of $\mathbf{4 8}$ hours in quite a number of cases treated, antibiotics were indicated and in the group 


\section{TABLE IV}

\section{HAEMATOMAS}

\begin{tabular}{|c|c|c|c|c|}
\hline & \multicolumn{2}{|c|}{ GROUP 'A' } & \multicolumn{2}{|c|}{ GROUP 'B' } \\
\hline Injuries & $\begin{array}{l}\grave{0} \mathscr{d} \\
\dot{0} \\
\dot{2}\end{array}$ & $\begin{array}{l}\text { Time Taken } \\
\text { for Resolution }\end{array}$ & 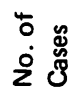 & $\begin{array}{l}\text { Time Taken } \\
\text { for Resolution }\end{array}$ \\
\hline $\begin{array}{l}\text { Haematoma forehead } \\
\text { no fracture of skull }\end{array}$ & ; 10 & 10 days & 10 & $15-20$ days \\
\hline Haematoma knee & 5 & 12 days & 5 & 3 weeks \\
\hline
\end{tabular}

TABLE V

\section{ANKLE SPRAIN AND BRUISING} WITHOUT FRACTURE

\begin{tabular}{|c|c|c|c|c|}
\hline & \multicolumn{2}{|c|}{ GROUP'A' } & \multicolumn{2}{|c|}{ GROUP 'B' } \\
\hline Injuries & $\begin{array}{l}\text { No. of } \\
\text { Cases }\end{array}$ & $\begin{array}{l}\text { Time Taken } \\
\text { to Clear }\end{array}$ & $\begin{array}{l}\text { No. of } \\
\text { Cases }\end{array}$ & $\begin{array}{l}\text { Time Taken } \\
\text { to Clear }\end{array}$ \\
\hline Bruising on lateral side & 20 & $10-12$ days & 20 & $2-3$ weeks \\
\hline Bruises on medial side & 10 & 8-10 days & 12 & 14-21 days \\
\hline Bruises on foot & 4 & $10-12$ days & - & - \\
\hline
\end{tabular}

\section{REFERENCES}

1. BLONSTEIN, J. L. (1960) The Practitioner, 185, 78.

2. BOYNE, P. S. (1967) The Practitioner, 198, 543-546.

3. LIE, K. K., LARSEN, R. D., et al. (1967) Surg. Gynec. Obstet., 125, 595-597.

4. SHAW, P. C. (1969) Brit. J. clin. Pract. 23: 1.

5. THEVENOT, R., et al. (1966) Therapie, XXI, 457-472.

6. SENECA, H., PEER, P. (1965) J. Amer. Geriat. Soc., 13, 8, 708-717. where Chymoral was also used the incidence of infection was reduced very quickly. The mode of action in potentiating the action of antibiotics is not yet fully understood but Thevenot ${ }^{5}$ and Seneca \& Peer $^{6}$ have shown that it is possible to achieve a better concentration of the antibiotic at tissue level by their concomitant use.

It is obvious from these results that the proteolytic enzymes do, in fact, help to reduce the infection associated with accidental injuries.

\section{Acknowledgements}

We express our sincere thanks to $\mathrm{Mr}$. P. I. Hywel-Davies, F.R.C.S., Consultant Orthopaedic Surgeon, for his kind permission to carry out the trial study and publish the Report. Our sincere thanks to the Nursing Staff of the Casualty Department of the Dorset County Hospital, Mrs. J. Santell, the Hosptial Photographer for their kind co-operation and help. We extend our thanks to Armour Pharmaceutical for supplying up-to-date literature and gratitude to the West Dorset Group H.M.C. for the liberal supply of Chymoral tablets, irrespective of cost. Last, but not least, we must take this opportunity to thank Mrs. P. A. Walter for the tedious role of type script which she executed very skillfully. 


\title{
BILATERAL RUPTURE OF PECTORALIS MAJOR; A UNIQUE EXPERIENCE
}

\author{
J. E. BUCK, F.R.C.S.
}

22 Hill Crescent, Bexley, Kent.

\begin{abstract}
symptoms, pre and post-operative treatment and final recovery.

\section{Introduction}

The most recent article on this subject by Park and Espiniella (1970) quotes only 29 cases in the English literature but McEntire (1970) has found a total of 50 , one of which is a re-rupture after suturing but none is bilateral. The original description is attributed to Patissier (1822) in which a butcher's boy "died of the inflammation which supervened". The present case shows an advance from butcher's boy to consultant orthopaedic surgeon and from death by the evil humours to full functional recovery.
\end{abstract}

ABSTRACT

The subject is introduced with a brief review of the literature. The case history is given with an account of the

The second rupture is described and compared with the first and a further case of untreated unilateral rupture is recorded and the patients compared in respect of pain sensitivity and disability tolerance.

Case history: No. 1

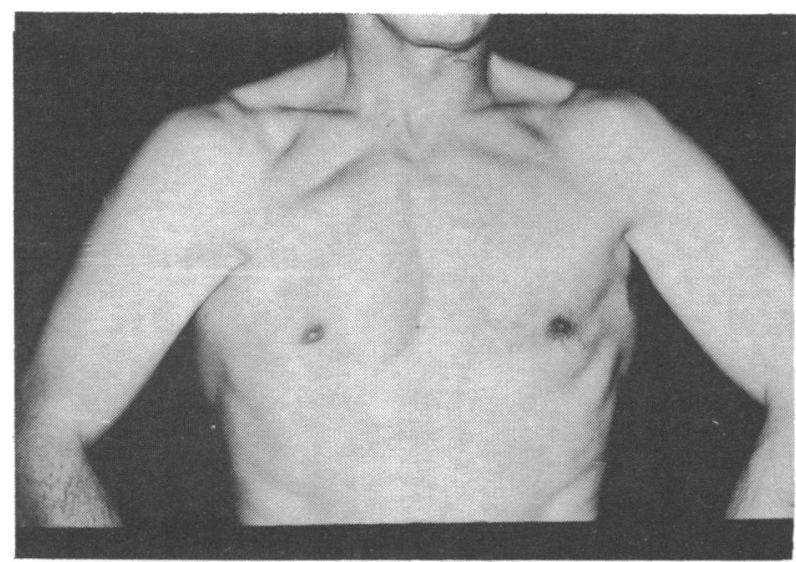

Fig. 1. Pre-operative condition two weeks after injury - the clavicular head is clearly intact. The scar is from a previous Bankart's repair, done after five dislocations.

A consultant orthopaedic surgeon, aged 46, was vaulting over a fence with both hands on top of it when a severe pain was felt in front of the right shoulder. Subjective diagnosis was difficult owing to mild neurogenic shock but was established within a few days by a senior colleague. Operation was delayed for two weeks during which time the muscle was supported by a ventfoam sling. Figs. 1 and 2 show the preoperative

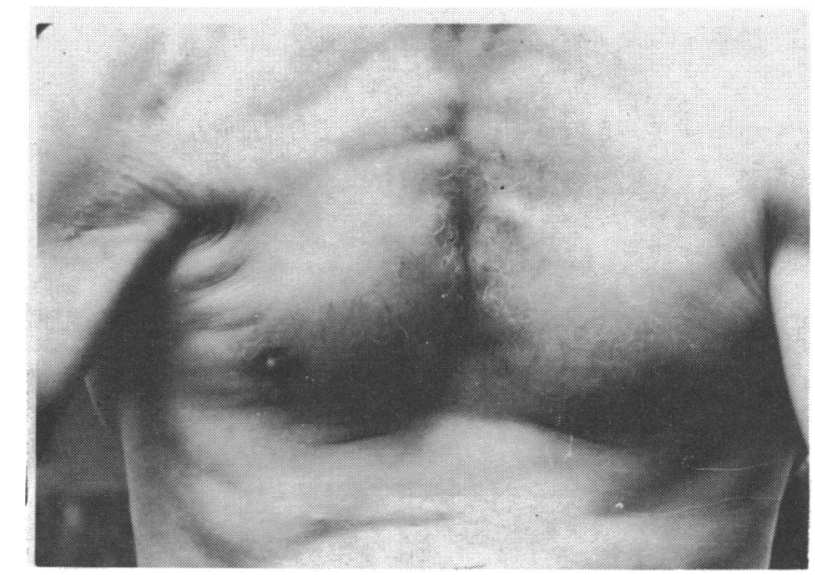

Fig. 2 The deepening of the axilla and drag on the deep fascia of the arm together with the bunching of the sternal head.

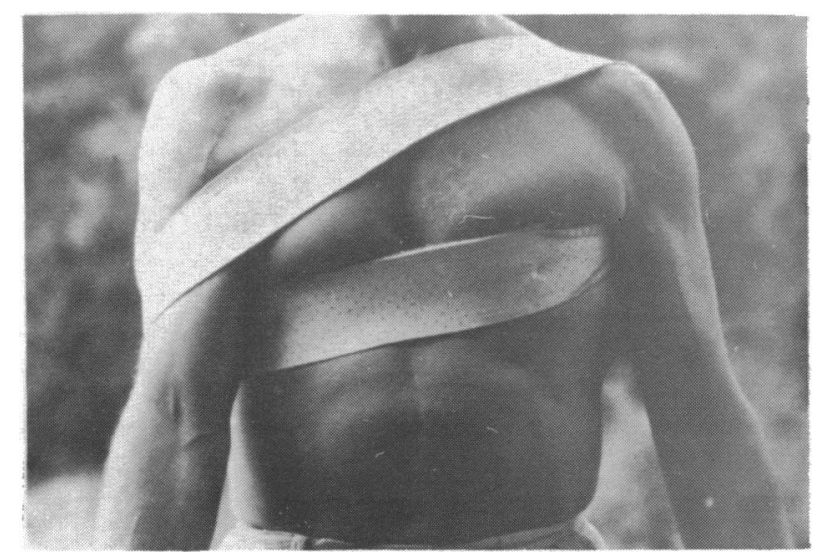

Fig. 3. The supporting sling in use postoperatively "ventfoam".

condition and fig. 3 the sling in position, allowing a backward movement of the left shoulder to produce a reasonably forceful flexion and adduction of the injured arm through a limited range. Without the sling orthopaedic operating was impossible and the weakness 
complained of by some patients was due in this case to painful inhibition and attempts to test the true strength of the muscle could not be tolerated. This patient was also noted to have a low pain threshold, to be referred to later. The pain was similar to that in any other torn muscle but was referred across the axilla and down the inner side of the arm as a tearing sensation in the fascia.

Operative repair was carried out by Mr. David Trevor, who had previously performed a Bankart's repair on the same shoulder. Figs. 4, 5 and 6 show the rounded,

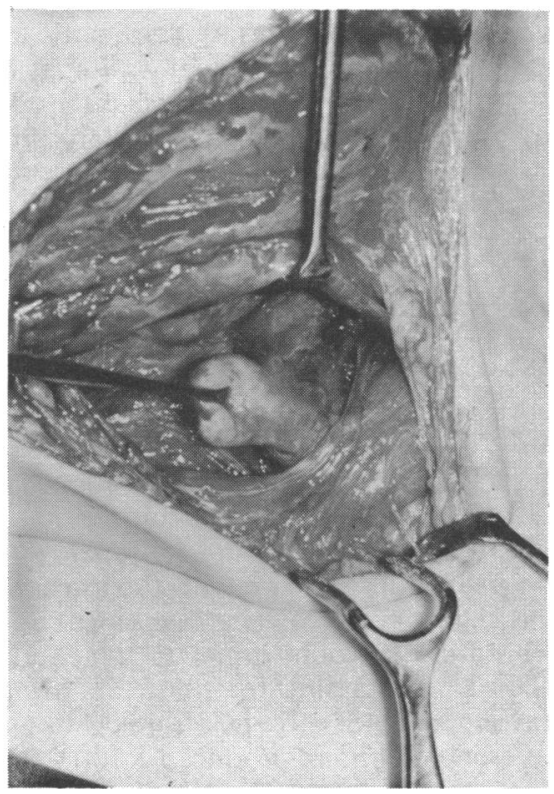

Fig. 4. Deltoid and clavicular head retracted upwards.

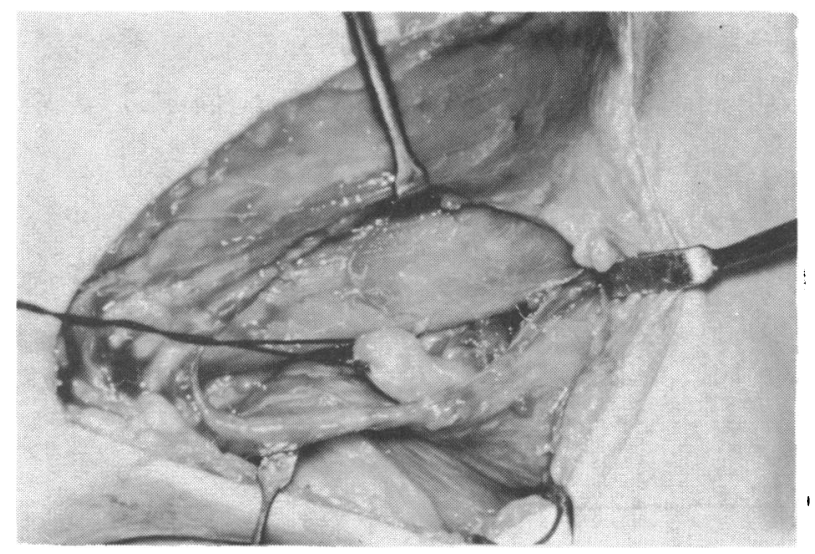

Fig. 5. The suture in position.

retracted tendon of the sternal head of the muscle being resutured to the humeral shaft. Fig. 7 shows the degree of elevation achieved at three weeks and fig. 8 shows the

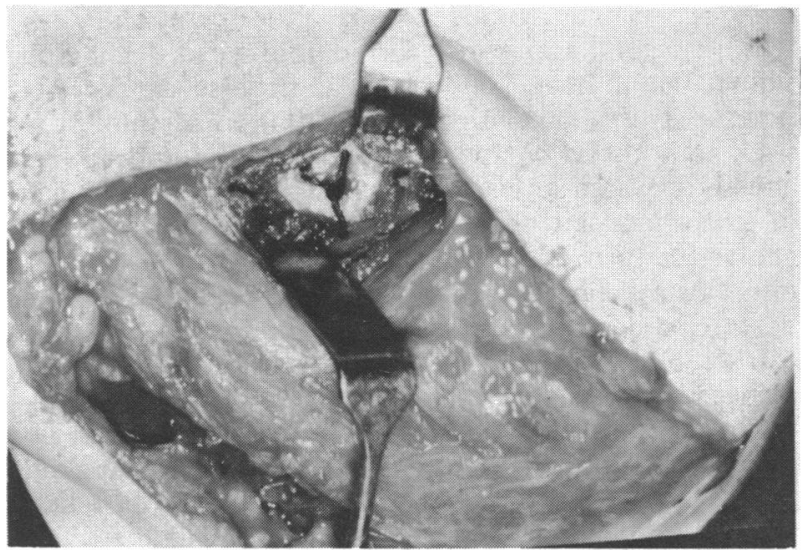

Fig. 6. The suture tied through the humerus.

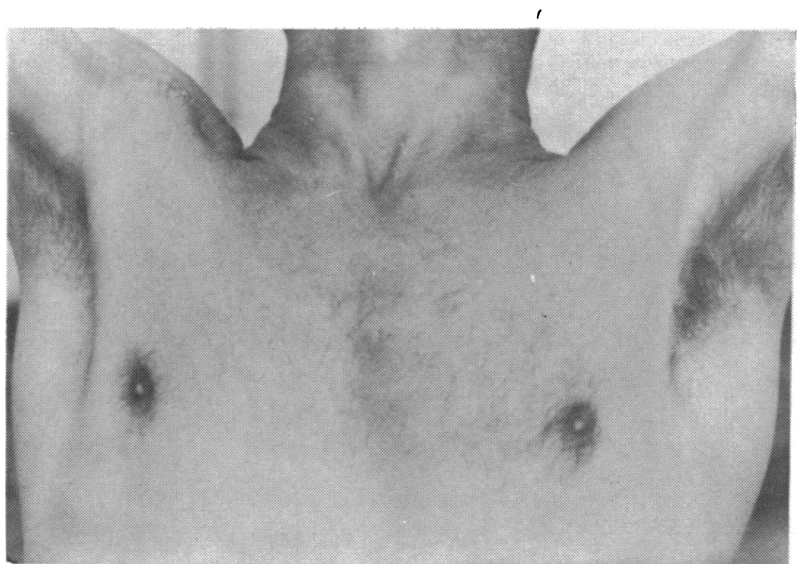

Fig. 7. Degree of elevation three meeks after operation - the anterior axillary margin is tight!

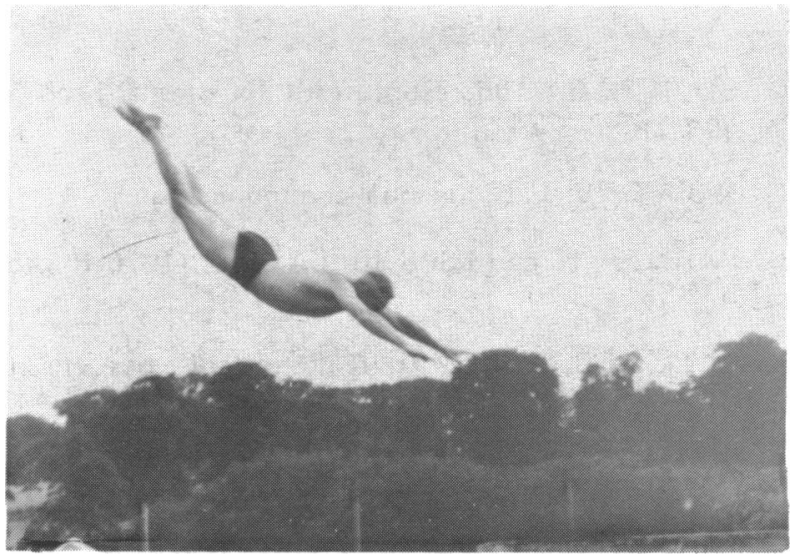

Fig. 8. The after treatment - same day as 7. Three metre board.

after treatment at that time. The supporting sling was used for all activities for three weeks and for heavy work during the second three weeks, full power and range 
being achieved at about six weeks after operation.

The second rupture occurred four years later while skiing. On a steep, icy left hand traverse an excessive side-slip coincided with the implantation of the left ski stick thus throwing the full weight of the body on the already elevated left arm. Diagnosis was easy in the light of experience and the treatment was by the sling which allowed a further week's skiing in moderate discomfort only. Pain relieving drugs varied from omnopon, one dose to cognac, several doses and operative repair was carried out by Mr. Robert Sewell and once more full recovery took six weeks but a return to normal operating (with the sling) was possible in two. The patient has since skied on snow and water, swum a mile "butterfly", climbed ropes and even vaulted over fences. It was interesting to note that this patient required

Case history: No. 2

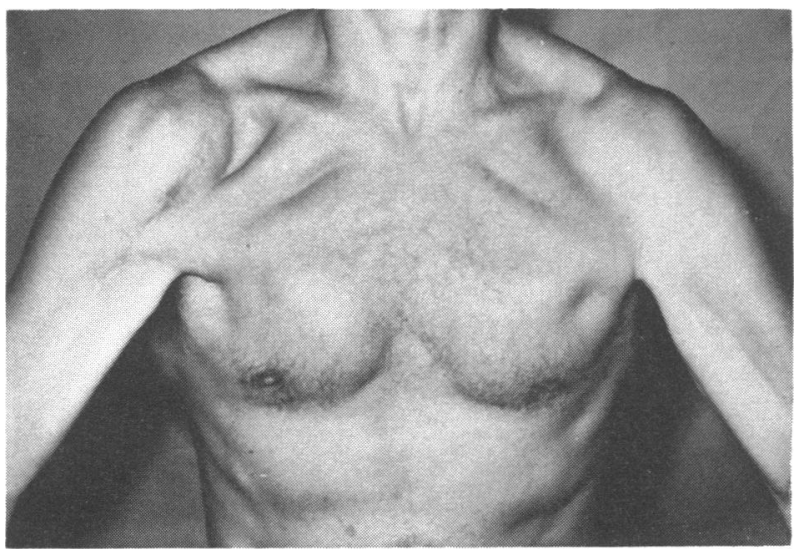

Fig. 9. 8 years after right repair -4 years after left. morphine or pethadine for four or five nights after each operation, including the Bankart and the lesser analgesics appeared to have no effect at all. The normal patient only requires the strong drugs for $\mathbf{2 4}$ hours after these procedures and occasionally aspirin alone has sufficed.

Many recorded cases have not been operated on and my second case is one of these. R. G., aged 38, a painter, was standing beside a heavy ladder which fell over and as he grabbed it he felt a sudden pain in the right upper arm. This was followed, during the next 24 hours by extensive bruising of the inner side of the arm but the patient was not off work and felt only moderate discomfort. The symptoms gradually disappeared over the next six to eight weeks and left a slightly odd feeling due to the fascial pull across the axillary floor. The patient had no occupational disability and no hobbies of a physically violent nature. When examined five years later the power of the right arm was $90 \%$ normal.

\section{Discussion}

It is clear that these two patients have considerably different standards of pain as well as different tolerances of disability. The surgeon felt moderately severe pain both after the injuries and the operations and was sufficiently intolerant of the disability, in spite of reading the literature, to seek surgical repair -- twice; whereas the painter just got on with the job and has put up with the slight inconvenience ever since. Certainly I know which patient I would prefer to treat and I would therefore like to pay a sincere tribute to the courage, forbearance and skill of my two surgical friends who took me on as a patient and produced a $100 \%$ functional result.

\section{REFERENCES}

1. BUCK, J. E.: 1963 Rupture of the sternal head of pectoralis major - a personal experience. J. Bone and Joint Surg., 45-B: 224.

2. MCENTIRE, J. E.: Personal communication.

3. PARK, J. Y. and ESPINIELLA, J. L.: 1970 Rupture of pectoralis major muscle. J. Bone and Joint Surg., 52-A: 577-581.

4. PATISSIER, P.: 1822 Traité des maladies des artisans: Paris: p.163: 1822. 
ALLOPLASTY OF SPORTSMEN'S LIGAMENTS

\author{
Prof. Z. S. MIRONOVA, M.D., G. I. LAVRISTCHEVA, M.D. \& E. V. BOGUTSKAYA, M.D. \\ Central Institute of Traumatology \& Orthopaedics, Moscow, U.S.S.R.
}

\begin{abstract}
$20 \%$ of all traumas of the knee joint. with the help of lavsan fibres.

\section{Introduction}

Injury of the cruciate ligaments of the sportsman's knee joint, as our investigations showed, takes place in 20 per cent of all traumas of the knee joint, and always causes disturbance of joint function. In the injured joint the mobility of the articulation surfaces becomes abnormal which in its turn leads to the involvement of the menisci, the cartilaginous surface of the joint, intra-articular adipose tissue and this leads to osteoarthrosis deformans.
\end{abstract}

ABSTRACT

Injury of the anterior cruciate ligament of the sportsmen's knee joint, as our investigations showed, takes place in

Existing methods of plastic reconstruction of the ligaments differ from each other by choice of plastic material. The commonest method is that of autoplasty, but it is connected with an extra trauma which is undesirable with sportsmen.

Nowadays synthetic fibres/capron/lavsan are mostly used as plastic material.

In the sport trauma department (Chief: Prof Z. S. Mironova) from 1962 to 1969, 125 patients were operated on

At present the most effective treatment of cruciate ligament damage in sportsmen is by surgery, which gives good immediate and late results where the indications for operation have been determined correctly.

A number of different methods of plastic reconstruction of the cruciate ligaments have been suggested and used.

We do not want to discuss the results of fresh ligament injury treatment, for we do not possess enough observations for proper assessment.

Existing methods of plastic reconstruction of chronic ligament rupture differ from each other mainly by the choice of plastic material. The most used method is that of autoplasty (Grekov, Sitenko, Landa, Gay-Grovers, etc.). But all these methods are connected with an extra trauma which is undesirable with sportsmen.

Nowadays synthetic fibres ("capron", "lavsan") are mostly used as plastic material.

In the sport trauma department under the direction of Professor Z. S. Mironova, from 1962 to 1969,125 patients were operated on with the help of lavsan fibres.
Lavsan fibres were used by us as implantation material because of their mechanical stability which is preserved with multiple flexions and in the transition of the fibres into the moist condition. Many authors, including ourselves, have proved the harmlessness of the lavsan implantation into the organism, namely into the cavity of the knee joint. Synovial membrane reaction does not differ from other operative procedures.

Pre-operatively special attention is paid to the condition of the quadriceps muscle. We consider it advisable to undertake a course of special physical exercises, manual massage and electrostimulation of the muscles through the Bernard current apparatus.

At operation, the articular cavity is exposed by means of a Pair incision. The joint is examined. In the case of internal meniscus injury the damaged part is removed through the same incision. In the case of external meniscus injury an extra external parapatellar incision is made. The channels of the tibia and femur were bored with the help of drill parallel to the ligament direction. Lavsan band was laid through these channels with the help of special instruments. If the ends of the torn ligament were present the lavsan band is laid through them. On the femur it is fixed by a knot, after which the distal ligament end is stretched. After the tension of the newly formed ligament and forward or backward mobility of the tibia on the femur have been tested the distal end of the lavsan band is fixed on the shin be means of intraosseal suture. A full leg plaster is put on with the knee joint in flexion of $175^{\circ}$ for three weeks. Four to five days post-operatively static contractions are given to the quadriceps, and at ten days electrostimulation is performed through windows cut in the plaster cast. By the time of discharge home the patient is ready for weight-bearing and the range of movements of the knee joint is usually about $90^{\circ}$ (we 
did not try to achieve a greater movement range) and no forward and backward mobility of the joint was observed. We allow training after the muscle apparatus is fully restored, which in case of a proper regime takes place 6.8 months after the operation.

At present we are studying the follow-up results of the operation technique. Most of those operated upon from one to seven years previously may be considered good. The patients do not complain of pain in the operated joint and they can load their extremity completely. Along with a big number of good results there are satisfactory and bad ones. We consider that delayed surgical intervention is the main cause of unsatisfactory results because the pathological changes in the joint itself and in the extremity as the whole (we mean osteoarthrosis and muscle atrophy) could not be reversed even with the help of adequate ligament formation. We believe that bad results were connected with the faults in the operative techniques, latent infection and incompatibility of recipient tissues with alloplastic material.

We had an opportunity to investigate the lavsan bands which had been playing the role of the cruciate ligament in the human knee joint during the period from $1 \frac{1}{2}$ to 2 years. We do not discuss the causes of the spontaneous disappearance of the newly constructed ligaments but we consider it necessary to say that in none of the cases was it a pathological state of the joint itself which could influence the process of regeneration.
The macroscopic investigations of the implant showed that instead of being white in colour it became yellow but the structure of the fibres remained unchanged. In some cases one end of the ligament was covered with a thin, transparent, easy removed film.

Microscopy showed germination of connective tissue among the lavsan fibres in narrow strips and among the lavsan bundles in wider strips. The connective tissue surrounding the lavsan fibres and bundles was not identical. At some areas it was granulation tissue with numerous leucocytes and giant cells; at other areas it was compact connective tissue with many segmental-nuclear lymphoid cells. Only among the walls of the lavsan ligament was compact connective tissue like a ligament found. In this tissue thick collagenous fibres were directed obliquely and longitudinally in relation to the lavsan ligament. At these areas inflammatory infiltrates were not present. The connective tissue everywhere was tightly connected with lavsan fibres and bundles. Germination of the ligament surface was observed in none of all cases investigated.

\section{Summary}

Our clinical and morphological investigations showed that alloplastic material can be successfully used for restoration of the knee joint ligaments, using "lavsan" fibres in 125 cases in 7 years.

\title{
HORNER'S SYNDROME OF TRAUMATIC ORIGIN \\ ${ }^{1} M$. DOCOVSKI, M.D. and ${ }^{2}$ N. HRISTOV, M.D. \\ ${ }^{1}$ Sportist Dispensary Polyclinic, "Bucurest", Skopje, Yugos/avia \\ ${ }^{2}$ Opthalmic Service, County Hospital, Bitola, Yugoslavia
}

\begin{abstract}
A typical case of Claude-Bernard-Horner's syndrome occurred in a football goalkeeper who fell against a goal post striking the top of his head.

Four or five months after the injury the first signs of trauma appeared including "subptosis" and "enophthalmos" together with a "myosis".

In presenting this example of a typical Claude-Bernard-Horner's syndrome of traumatic origin we stress the importance of blows upon the head and the fact that it may be three to six months before an accurate assessment of the significance and severity of the injury is possible.
\end{abstract}


TREATMENT OF SHOULDER INJURIES

M. AVREN, M.D.

1800 Logan Avenue, Winnipeg 3, Manitoba, Canada

The use of a New Shoulder Sling For Treatment of Injuries of the Shoulder Girdle and Upper Arm is described.

\section{Introduction}

Injuries about the shoulder girdle are very common in present day medical practice and occur very frequently in athletics such as football, hockey, wrestling, etc. (Also the incidence of such injuries is increasing as the result of traffic accidents.)

For treatment of these injuries we have developed a new type of shoulder sling which can be used very effectively in:

\section{Fractures of the clavicle}

2. Strains, subluxations and dislocations of the acromio-clavicular joint

3. Fractures of the scapula

4. Dislocations of the shoulder joint

5. Fractures of the proximal end of the humerus

The shoulder sling is employed in the conservative treatment of these conditions and may be used also for post-operative immobilisation when ever operative reduction may be required.

\section{Description of Surgical Shoulder Sling}

A very simple inexpensive device has been developed for the treatment of these injuries.

The main sling is placed over the shoulder and extends around the arm and forearm on the same side as the injury. There is a small pad applied to the shoulder and its position, pressure and direction can be adjusted as desired for the specific injury. Another pad is located below the forearm and attached to the sling to support the arm. The weight of the forearm maintains the desired pressure upon the shoulder pad.

Both pads are slotted for simple adjustment by the patient himself if necessary.

The sling itself is readily adjustable by the means of a Velcro fastener attached at the ends.

There is another strapping which is placed around the trunk of the patient and is attached to the main sling, and is also adjustable by Velcro ends. This strapping around the trunk readily facilitates lateral or medial positioning of the arm sling and shoulder pad as desired.

These slings are available for either right or left side and in large, medium and small sizes.

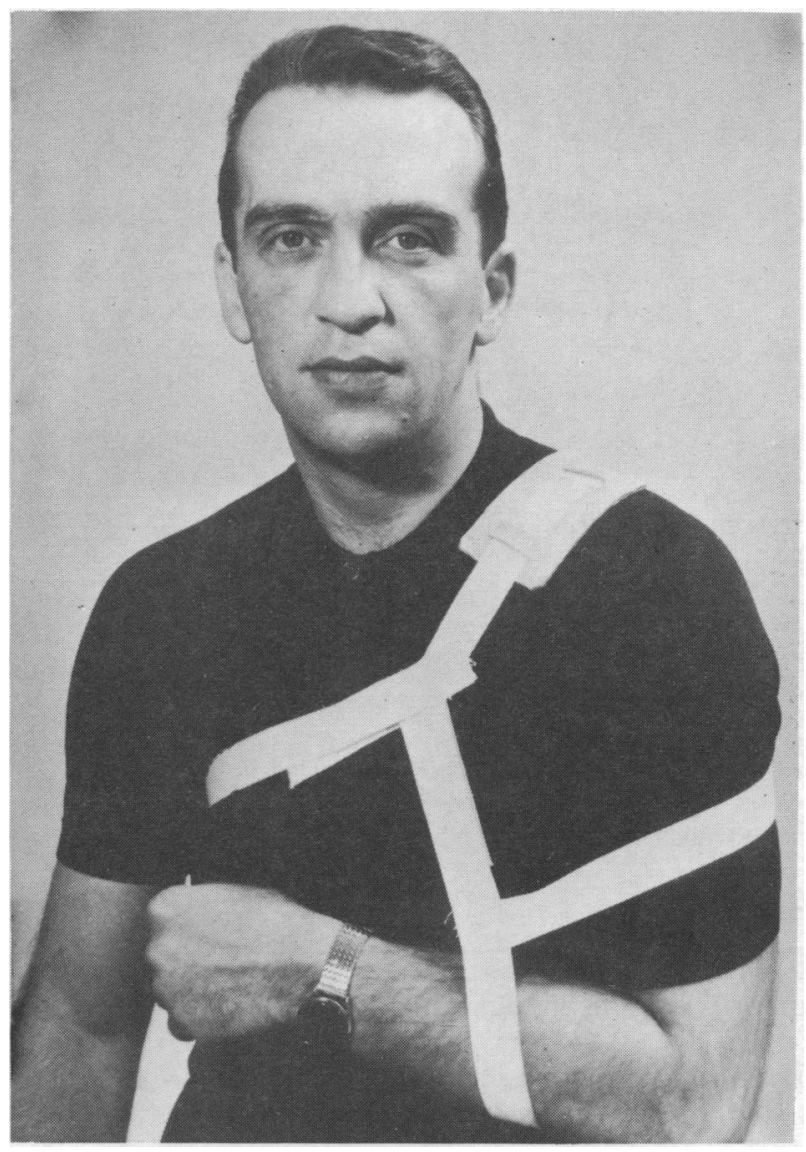

This shoulder sling is very simple to apply and to adjust and does away with the application of adhesive strapping whicil is often very uncomfortable to the patient, especially if required to wear for any length of time. Also many patients are sensitive to adhesive 


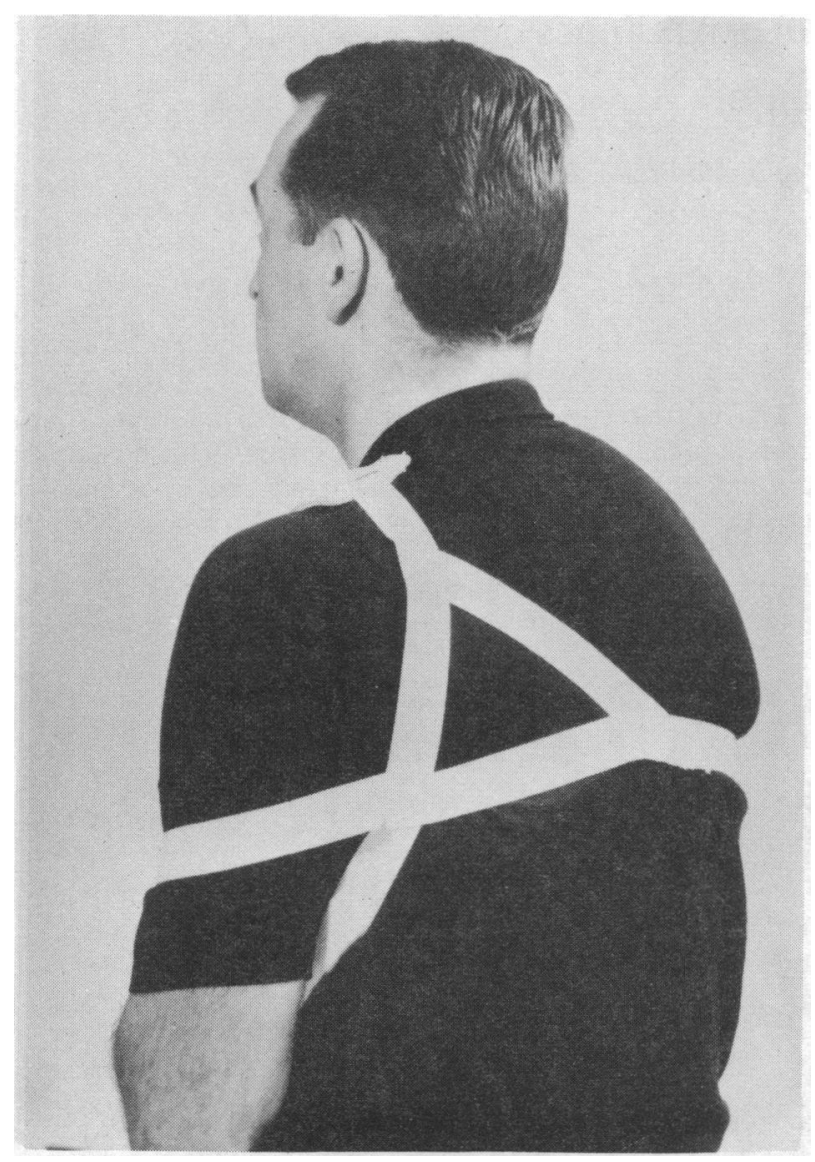

strapping and often develope severe skin reactions.

Furthermore with the use of this shoulder sling, exercises can be readily implemented even in the early stages of treatment while continuing essential immobilisation of the injured parts.

The sling can be applied on top of light clothing and over night attire with complete comfort and adequate immobilisation.

\section{Case Reports}

The following are representative cases which we have treated with this shoulder sling.

1. Mr. A. suffered a subluxation of the left acromio-clavicular joint in a soccer match.

He was treated immediately by the conventional method of the application of adhesive elastoplast strapping of the shoulder and arm.

Two days later, he complained of severe discomfort at the site of injury and also had developed a pruritic rash from the tape. Three days later the rash had become so severe it had spread over the entire trunk with considerable blistering of the skin. The strapping had to be removed and the shoulder sling was applied. This provided immediate relief and comfort to the skin, and to the injury site.

Shoulder, arm, wrist and hand exercises were also implemented at this time.

He wore the shoulder sling during the day over his shirt and during the night over his pyjamas.

At the conclusion of treatment four weeks later, there was no pain at the site of injury, there was no wasting of the musculature of the shoulder or limb, there was no stiffness of any of the joints, and functional movements of the shoulder and limb were completely normal at the time of discontinuing treatment.

2. Mr. L. suffered a fracture of the right clavicle in its middle third with superior angulation at the fracture site during a football game.

He was taken to hospital from the football game where $x$-rays revealed the fractured clavicle. Conventional adhesive strapping was applied. At 6 o'clock the next morning, he phoned to state that he had been in severe pain all night and had taken a total of $350 \mathrm{mgms}$ of Codeine orally in the past twelve hours with very little relief of pain.

Later that morning, the adhesive strapping was removed and the surgical shoulder sling was applied. He became quite comfortable immediately and required no further analgesics. Throughout the immobilisation with the shoulder sling, he was able to perform exercises of the limb to prevent any stiffening or loss of function.

The shoulder sling was discontinued five weeks later and he had completely normal functional movements of the injured shoulder and limb and there was no evidence of any stiffness nor muscle wasting.

Three other players of the same football team were also treated with this shoulder sling during that season - two of them for subluxations of the acromic-clavicular joint and the other for a dislocation of the shoulder. The results in all cases were excellent.

3. Miss E. McM., age 18, a student nurse was admitted to Misericordia General Hospital with a fracture of the neck of the glenoid of the right scapula. The 
glenoid process was displaced medially and anteriorly and also slightly inferiorly with an elongated fragment of bone anterior to the scapula and about one half inch medial to the glenoid.

On examination a young girl of good physical build, who complained of constant pain about the right shoulder. The right shoulder was painful to touch. Movement at the right shoulder was very limited by pain and muscular spasm. Laboratory tests were normal. She was given Demerol 50 mgms., p.r.n. for pain.

Two days after admission the shoulder sling was applied and the following day no further analgesic was required. She stated she was quite comfortable.

The following day she was out of bed in a chair and was discharged from the hospital four days later.

She wore the sling for one month. A very good functional result was obtained.

4. Douglas C. a three year old boy fell while playing and suffered a fracture of the right clavicle. The distal fragment was displaced downwards and medially to the extent of the width of the bone in each direction.

The conventional taping was applied with an ordinary arm sling. Three weeks later, there was still considerable discomfort at the fracture site and also cutaneous discomfort from the adhesive strapping. $X$-rays taken at this time showed no changes in the position of the fragments and no evidence of union. The adhesive strapping and arm sling were removed and the shoulder sling was applied. Remainder of the course was uneventful, the patient was very comfortable. In six weeks, $x$-rays showed union to be sound and the shoulder sling was discontinued. There was no loss of function of the limb and there was no muscular wasting present.

5. Billy R. was a fourteen year old boy who suffered a subluxation of his left acromic-clavicular joint when he fell over the handle bars of his bicycle. The shoulder sling was applied. The course of treatment was uneventful; graduated exercises were implemented during the course. The sling was discontinued four weeks later, during the day-time, and he was instructed to continue application of the sling during the night for two further weeks. An excellent result was obtained, there was no loss of function or muscular wasting at the time of completion of treatment.
6. Jerry V. a 25 year old male suffered a severe fracture of the right clavicle during a football practice. He was taken immediately to the hospital where $x$-rays showed a comminuted fracture of the middle of the clavicle. A central fragment appeared to be freely movable. The medial end of the distal portion was displaced downwards the width of the bone. At the hospital a staff doctor had applied the figure 8 elastoplast bandage. The patient was seen again three days later - he was having severe pain at the fracture site and marked discomfort, particularly in the axilla from the adhesive strapping. The strapping was removed and a shoulder sling applied, providing immediate relief of pain and discomfort. Throughout the course of treatment with this shoulder sling graduated exercises were implemented for the limb and shoulder and upon completion of treatment, there was excellent union with no wasting nor loss of function of the limb and shoulder.

Another interesting case which however was not a sports injury was:

7. Mrs. S. K. - a 76 year old female who fell at home and injured her right arm. She was taken to hospital immediately. X-rays showed a comminuted and impacted fracture through the surgical neck of the humerus with general position and alignment satisfactory. The greater tuberosity was displaced somewhat laterally. The shoulder sling was applied immediately. The course of treatment was uneventful and exercises of the limb were continued throughout. Seven weeks later, the wearing of the sling was discontinued during the day but maintained during the night and in another three and a half weeks the shoulder sling was discontinued completely, bony union was sound, and there was very little loss of function and no muscular wasting.

\section{Conclusion}

We have developed a surgical shoulder sling which is simple in construction and design and inexpensive.

1. We have used this sling for the past four years in a variety of injuries of the shoulder girdle and humerus with good results.

2. In our experience we have found this shoulder sling to be superior to any other type of treatment in current use, and finally, it is simple, inexpensive, and easy to apply, and is worn with considerable comfort. 


\title{
THE INFLUENCE OF WORK LOAD OF DIFFERENT DURATION AND INTENSITY ON HYPERTROPHY, PULLING STABILITY AND EXTENSION CAPACITY OF THE DENSE COLLAGEN CONNECTIVE TISSUE, e.g. ACHILLES TENDON.
}

\author{
Prof. Dr. Med. Habil. KURT TITTEL \\ 701 Leipzig (GDR), Friedrich-Ludwig-Jahn-Allee 59
}

\begin{abstract}
Rupture of the achilles tendon that occurs in training and competition makes us raise the fundamental question as to whether the connective tissues can be trained in the sense of qualitative adaptation.

To answer this problem, 70 Albino rats, (belonging to the breed of Wistar) of a same age and belonging to both sexes were submitted to a training on the conveyor of 120 days and of different duration and intensity. In the final result of the experiment with the animals it was possible to prove that the collagen dense connective tissue of the achilles tendon reacts very differently on the loads analogous to those given in the training. This fact was distinctly expressed:-
\end{abstract}

1) by a differential hypertrophy

2) by an increase of the pulling stability

3) by a simultaneous negligible decrease of the extension capacity.

\section{Problem and goal}

Achilles-tendon ruptures occurring in training and competition during the last years raise the fundamental question of the degree in which the dense collagen connective tissue is trainable in a sense of quantitative and qualitative adaptation and how it responds to work loads of different duration and intensity.

\section{Method}

For the solution of the problem 70 albino rats (belonging to the Wistar race) of either sex and being at the beginning of the experimental training 4 months old and on an average weighing $315 \mathrm{~g}$ (male) and $225 \mathrm{~g}$ (female) were exposed to a 120-days' treadmill training of the following kind:

an "endurance"-group of animals practised daily a 60-minutes' run in a speed of $40 \mathrm{~m} / \mathrm{min}$ thus running 2800 to $3000 \mathrm{~m}$ in a day (resulting from this, the final work load amounted to about $180 \mathrm{~km}$ );

an "interval"-group of animals carried out, 20 times daily, a one-minute run in a speed of $70 \mathrm{~m} / \mathrm{min}$ (between each distance there was intercalated a rest of one minute), thus in a 40-minutes' time a total distance of $1500 \mathrm{~m}$ was covered (resulting in a final work load of approximately $95 \mathrm{~km}$ );

a "speed"-group of animals ran at a velocity of 80 $\mathrm{m} / \mathrm{min} 4$ times daily 4 minutes with a 2 minutes' rest between each run, resulting in a daily performance of

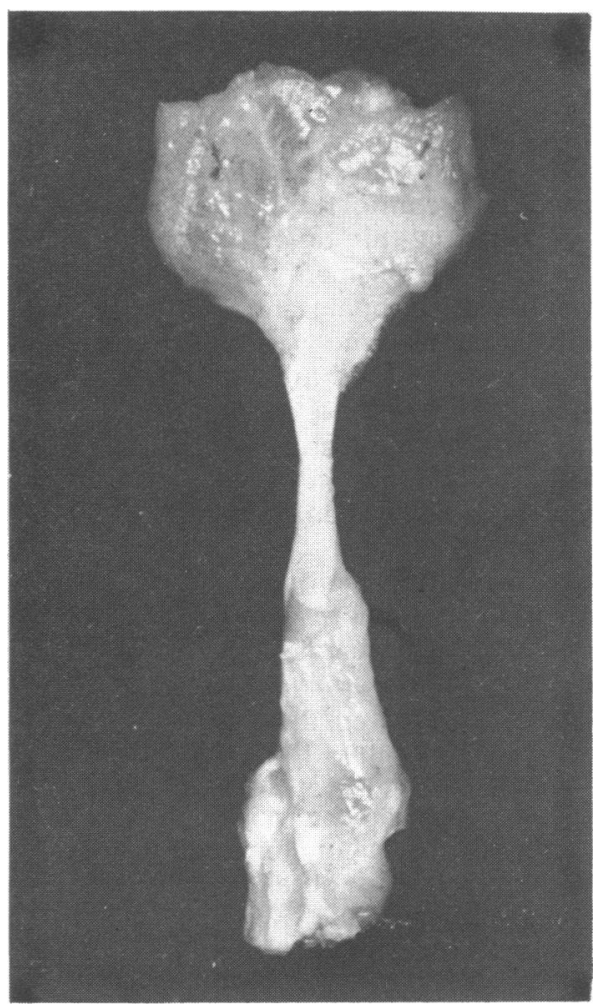

Fig. 1: Achilles tendon of an albino rat, proximally cut at the connection of muscle and tendon, but at the calcaneus she is maintained; 3: 1. 
about $1300 \mathrm{~m}$ (corresponding to a final work load of approximately $90 \mathrm{~km}$ ).

The training time was for all exercise groups of either sex between 14.00 and 18.00 o'clock and covered the period from February to June. The temperature in the room came to $220 \mathrm{C}$ on an average.

Immediately after the end of the training cycle, the animals were killed (by a blow on the neck), their achilles tendons were loosened by blunt dissection in a precise manner, and the tendons cut proximally at the connection of muscle and tendon, but at the calcaneus they were maintained (fig. 1). In order to avoid water losses of the material (which essentially change - as is well-known - not only the elasticity, but also the stability of the dense, collagen connective tissue), the investigations of the pulling stability and extensibility as a rule were carried out immediately after the removal of the tendon. The preparations were kept in the refrigerator in a temperature of $20 \mathrm{C}$, in a physiological saline.

The determination of the tendon cross section was carried out at the weakest spot (a little above the calcaneus) by means of a big tool microscope of CARL ZEISS of Jena, the basis of each determination of diameter being four thickness determinations of the tendon, and the average value being used for the computation.

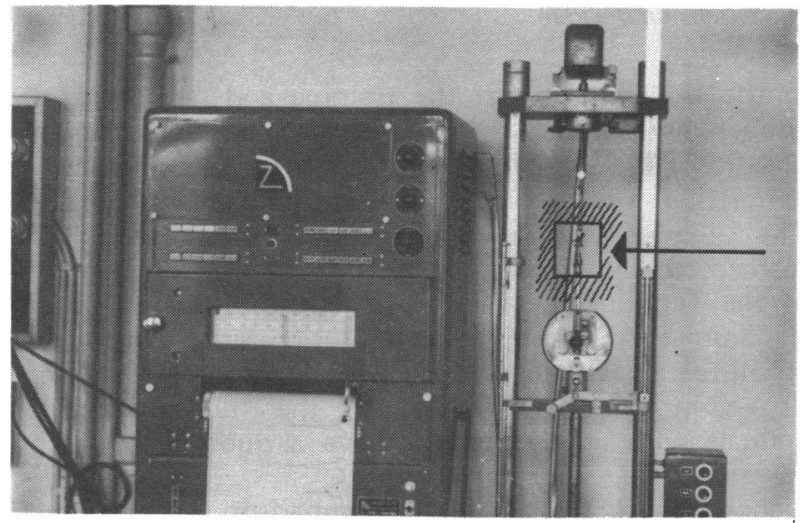

Fig. 2: Testing machine (with electronic indicator and recorder) for the trial of the pulling stability and extensibility.

For the trial of the pulling stability and extensibility, special testing machines (with electronic indicator and recorder) of the German Board of material and goods trials in Halle-Trotha and of the Institute of organic polymers of the German Academy of Sciences in Leipzig were used (fig. 2); for this reason, the tendon preparation was spanned between two small hand vices (fig. 3a): the rounded vices of which, serrated in an undulatory way, assured the fact that the pulling equally continued to the dense, collagen connective tissue.

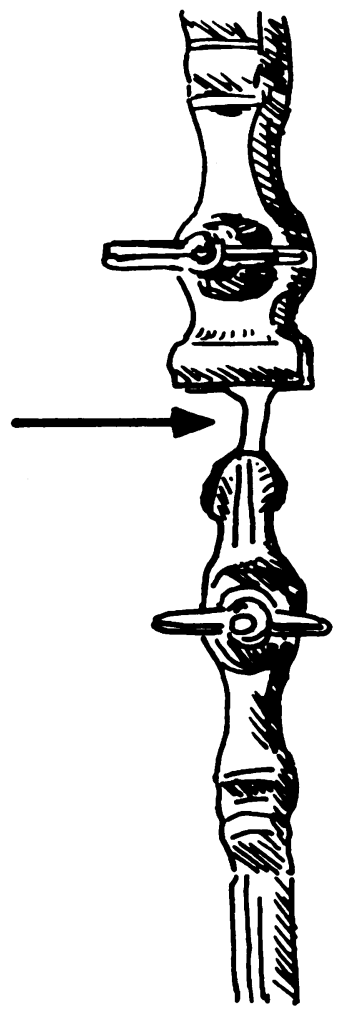

Fig. 3a: Two small hand vices of the testing machine with the tendon preparation spanned between them; 3:1.

The diagrams permitted the evaluation of the strength and extension coordinates (fig. 3b). For the strength coordinates, this was made each time in the breadth direction of the diagram paper (subdivided in a 100 intervals each corresponding to one per cent of the maximum strength value); thus one strength coordinate of 67 units in the scope of measurement $(20 \mathrm{~kg})$ means 67 per cent of $20 \mathrm{~kg}=13.4 \mathrm{~kg}$. In the evaluation of the extension coordinates the fact is at first to be considered that in the diagram the distance till the moment of the whip-crack-like rupture of the tendon is to be considered as an "extension" (in the fig. 4 corresponding to the sector $a \rightarrow b$, whereas the distance $b \rightarrow c$ is conditioned by the time of the reverse of the compensator). When using extension scales deviating from $1: 1$, the extension value must still be divided by the magnification factor (in fig. 4 being " 30 "). An extension of $12 \mathrm{~mm}$ this means, in a magnification of $30: 1$, a real extension of $12: 30=0.4 \mathrm{~mm}$; in a (constant) holding length of the tendon preparation of $5 \mathrm{~mm}$ the extension in per cent then amounts to $100 \cdot 0.4=8$ per cent 

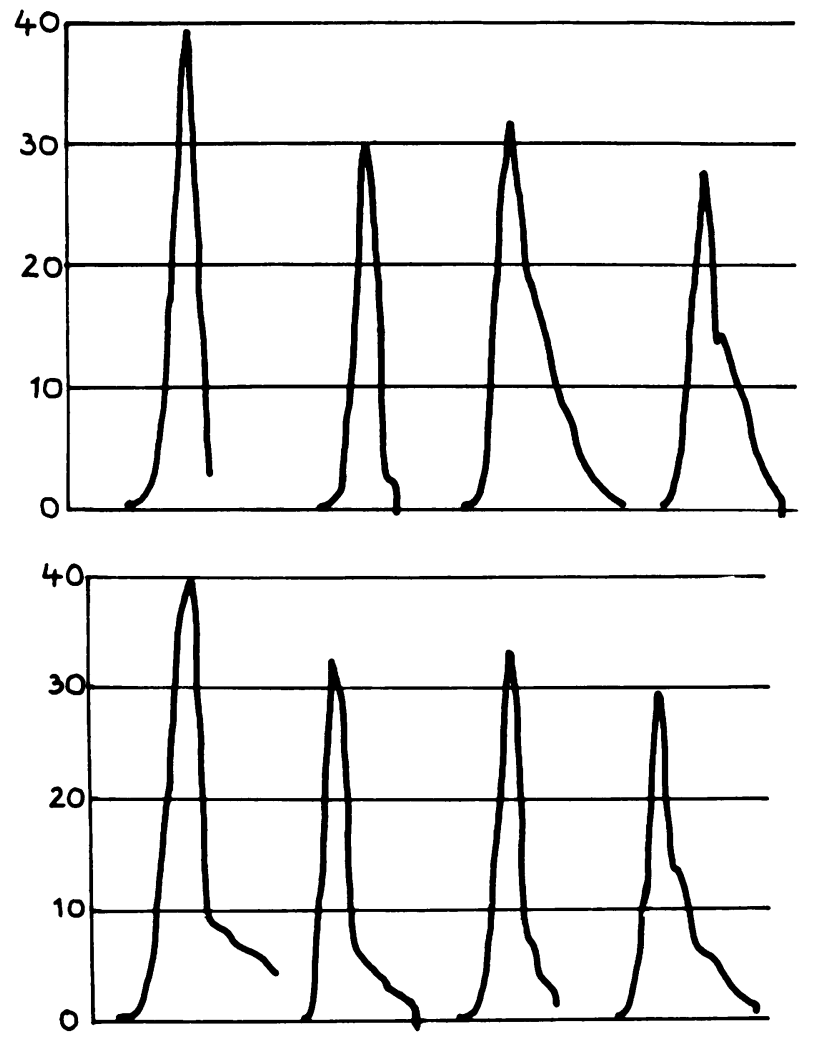

Fig. 3b: Several diagrams of the testing machine permitting the evaluation of the strength and extension of the tendinous tissue.

\section{Findings}

\section{Weight modifications:}

Since the body weight determined for each animal every day in the course of the experimental training is important in considering our problem, the weight modifications in the rest animals and the training animals stand before the other results (fig. 5 and 6 ). Whereas in the course of the training-cycle the body weight of the rest (control) animals of either sex was constantly rising (for which in the first place the higher amount of fat is responsible), the "endurance-run" and "interval" animals regularly lost weight from the 3rd week of training, and the "speed" animals so even immediately after the beginning of the experimental training already. This loss of weight was always more distinct in male rats than in the females. The lowest body weight was found in the 6th and 7 th training weeks; then it rose again, it is true, but it never returned, even approximately, to the initial value.

\section{Quotient of tendon-area and weight of animal:}

In order to eliminate the differences sometimes essential

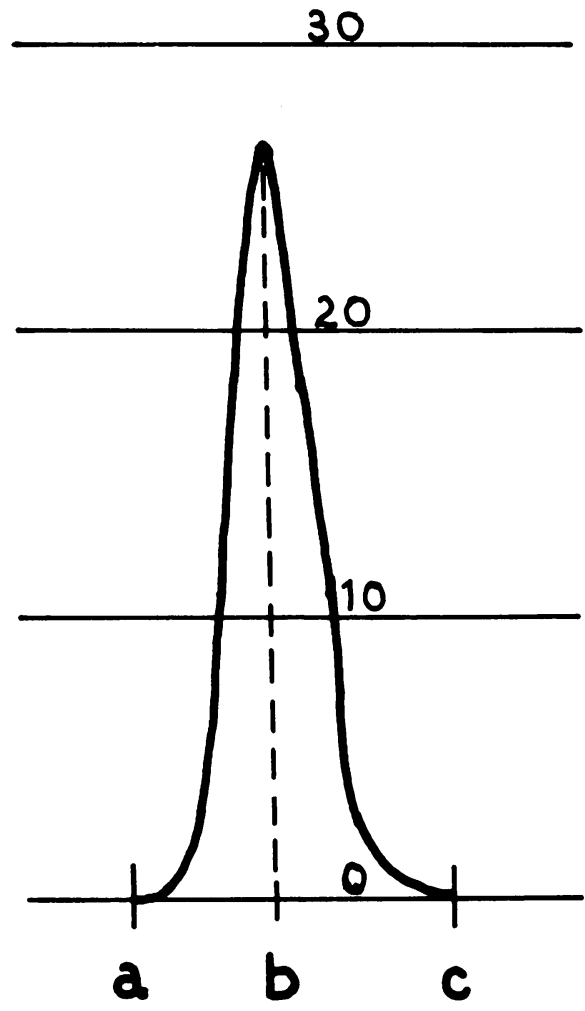

Fig. 4: "Extension" and time of the reverse of the compensator in a extension-diagram.

in the body weight of the training and rest (control) animals (with their effects on the tendon cross-section in question), it was necessary to choose a reference value permitting a comparison between the diverse groups. The "tendon-area and animals' weight quotient" was formed, which allowed for each animal to find the area of the Tendon cross-section for $100 \mathrm{~g}$ of the weight of the animal. According to that - in consideration of the absolute values and the difference in per cent (fig. 7 and 8) -, in the male albino rats the "endurance-run" animals with $\bar{x} 0.43 \mathrm{~mm}^{2}$ have a quotient which is $\frac{100 \mathrm{~g}}{100}$

higher by 22.50 per cent in comparison with the rest (control) animals ( $\left.\bar{x} 0.34 \frac{\mathrm{mm}^{2}}{100}\right)$ ! In the "speed" animals $100 \mathrm{~g}$

it is higher by 14.70 per cent amounting to $\bar{x} 0.39 \frac{\mathrm{mm}^{2}}{100 \mathrm{~g}}$

and in the "interval" animals by 11.77 per cent with $\bar{x}$ $0.38 \mathrm{~mm}^{2}$. In the female albino rats also, in which the $100 \mathrm{~g}$

rest (control) group had a tendon-area to animals' weight quotient of $\bar{x} 0.34 \mathrm{~mm}^{2}$ (thus exactly being in accord $\overline{100 \mathrm{~g}}$

with the initial value of the male animals), the "endurance-run" individuals had the biggest quotient 


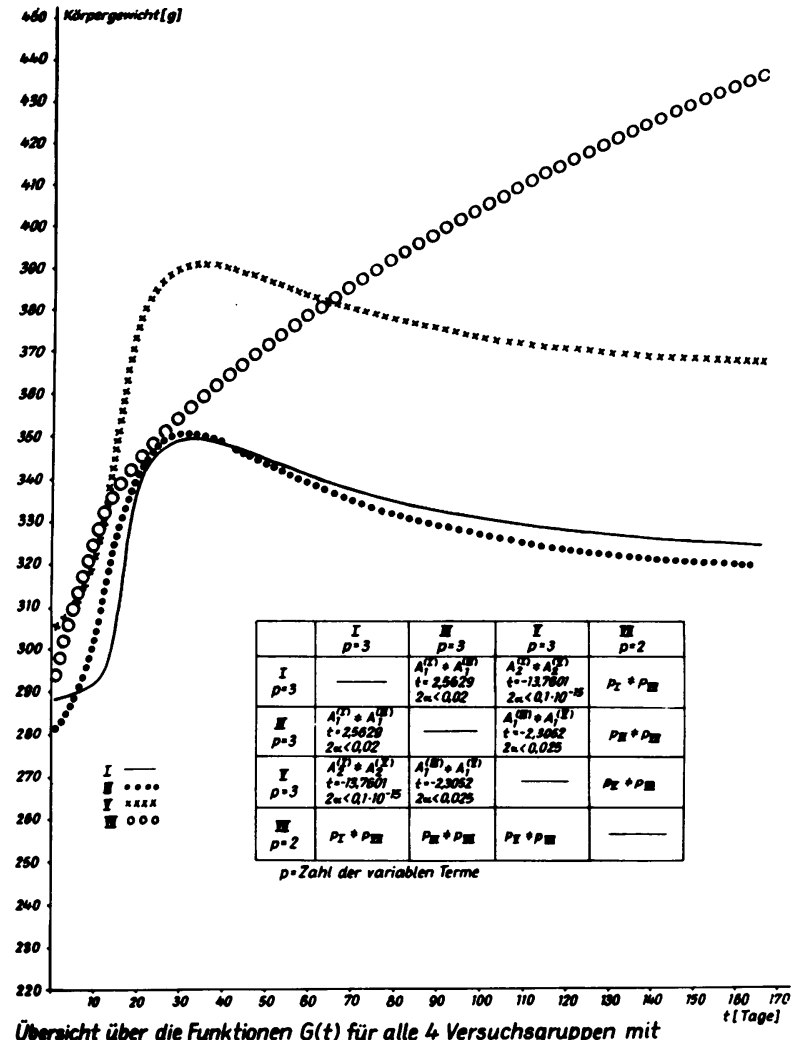

Ürrecht über die Funktionen $G(t)$ für alle 4 Versuchsgruppen mit mannlichen Teren

Fig. 5: The weight modifications in the male rest animals and training animals; VII: rest animals; III: "speed" animals; V: "endurance-run" animals; I: "interval" animals.

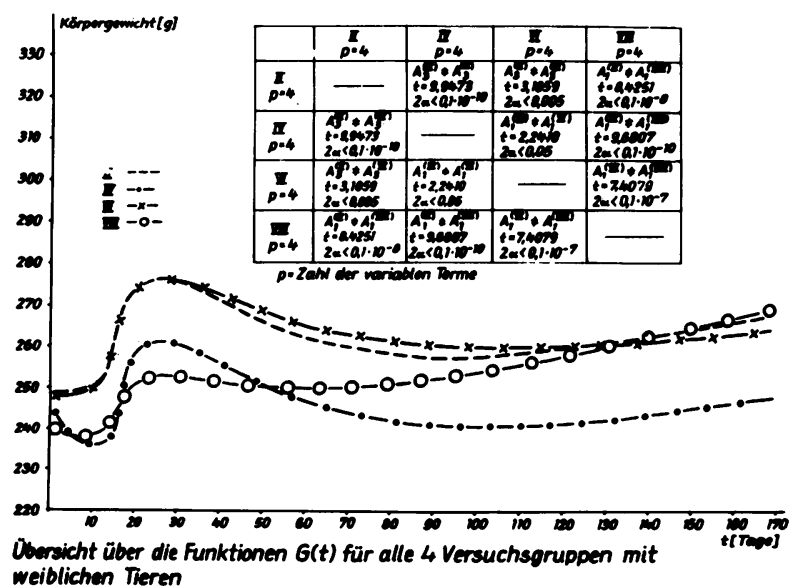

Fig. 6: The weight modifications in the female rest animals and training animals; VIII: rest animals; IV: "speed" animals; VI: "endurance-run" animals; II: "interval" animals. with $\bar{x} 0.40 \frac{\mathrm{mm}^{2}}{100 \mathrm{~g}}$ (= 17.64 per cent of augmentation), $100 \mathrm{~g}$

then followed the "interval" animals with $\bar{x} 0.38 \frac{\mathrm{mm}^{2}}{100 \mathrm{~g}}$

(= 11.70 per cent of augmentation), and the "speed" animals with $\bar{x} 0,37 \frac{\mathrm{mm}^{2}}{100} \quad(=8.82$ per cent of

augmentation). Consequently, the tendon-area to animals" weight quotient of the "endurance-run" animals of either sex is distinctly the greatest one (although the values of the females are a little inferior to those of the males, which is constitutionally conditioned; Schobert 1966, Wellmitz 1968). The greater tendon cross-section areas per $100 \mathrm{~g}$ of animal weight in the training animals in general (and in the "endurance-run" animals in particular) may be interpreted as the expression of a distinct tendon hypertrophy, which already Riede (1963) and Rollhäuser (1954) described for the achilles tendon.

\section{Pulling stability of the tendon:}

The pulling stability of the tendon (measured in $\mathrm{kg} / \mathrm{mm}^{2}$ ) showed (fig. 7 and 8 ) in the male "endurance-run" animals an augmentation of 15.68 per cent $\left(\bar{x}, 5.91 \mathrm{~kg} / \mathrm{mm}^{2}\right)$, in the "speed" animals one of 10.55 per cent $\left(\bar{x} 5.64 \mathrm{~kg} / \mathrm{mm}^{2}\right)$, and in the "interval" animals one of 8.45 per cent $\left(\bar{x} 5.25 \mathrm{~kg} / \mathrm{mm}^{2}\right)$ in comparison with the rest (control) animals ( $\bar{x} 5.11$ $\mathrm{kg} / \mathrm{mm}^{2}$ ). For the female albino rats, there was an augmentation of the pulling stability of the tendon by 13.63 per cent $\left(\bar{x} 5.75 \mathrm{~kg} / \mathrm{mm}^{2}\right)$ in the "endurance-run" animals, in the "interval" animals by 9.29 per cent ( $\bar{x}$ $5.52 \mathrm{~kg} / \mathrm{mm}^{2}$ ), and in the "speed" animals by 8.85 per cent $\left(\bar{x} 5.48 \mathrm{~kg} / \mathrm{mm}^{2}\right)$ in comparison with the rest (control) animals $\left(\bar{x} 5.06 \mathrm{~kg} / \mathrm{cm}^{2}\right)$. In all the pulling efforts (fig. 9) there was a relatively important extension $\left(D^{1}\right)$ at the beginning of the work load, in which a certain "stretching" of the tendon was conspicuous. Then in the curve there was a sharp rise $\left(D^{2}\right)$ corresponding to a phase of less extension. $\ln D^{3}$, the curve becomes again flatter, the extension again more important corresponding to the turning-point in the course of the curve, in the scope of which there are, accompanied by a distinct sound, deformations within the dense, collagen connective tissue; the summation of minimal slits in the tendinous tissue during the pulling work load in $D^{3}$ led finally to the - total rupture occurring in 89 per cent of all the cases at a "typical" spot (in the distal third of the tendon), while in the other cases the rupture occurred immediately at the calcaneus. The distinct augmentation of the pulling stability of the achilles tendon generally found in the training animals $($ and in particular in the "endurance-run" individuals) - its values are essentially superior to the indications made by Triebel (1902) and Stucke (1950), who described a pulling stability of $\mathbf{5 . 0 0}$ resp. $4.67 \mathrm{~kg} / \mathrm{mm}^{2}$ for the tendinous tissue - is 


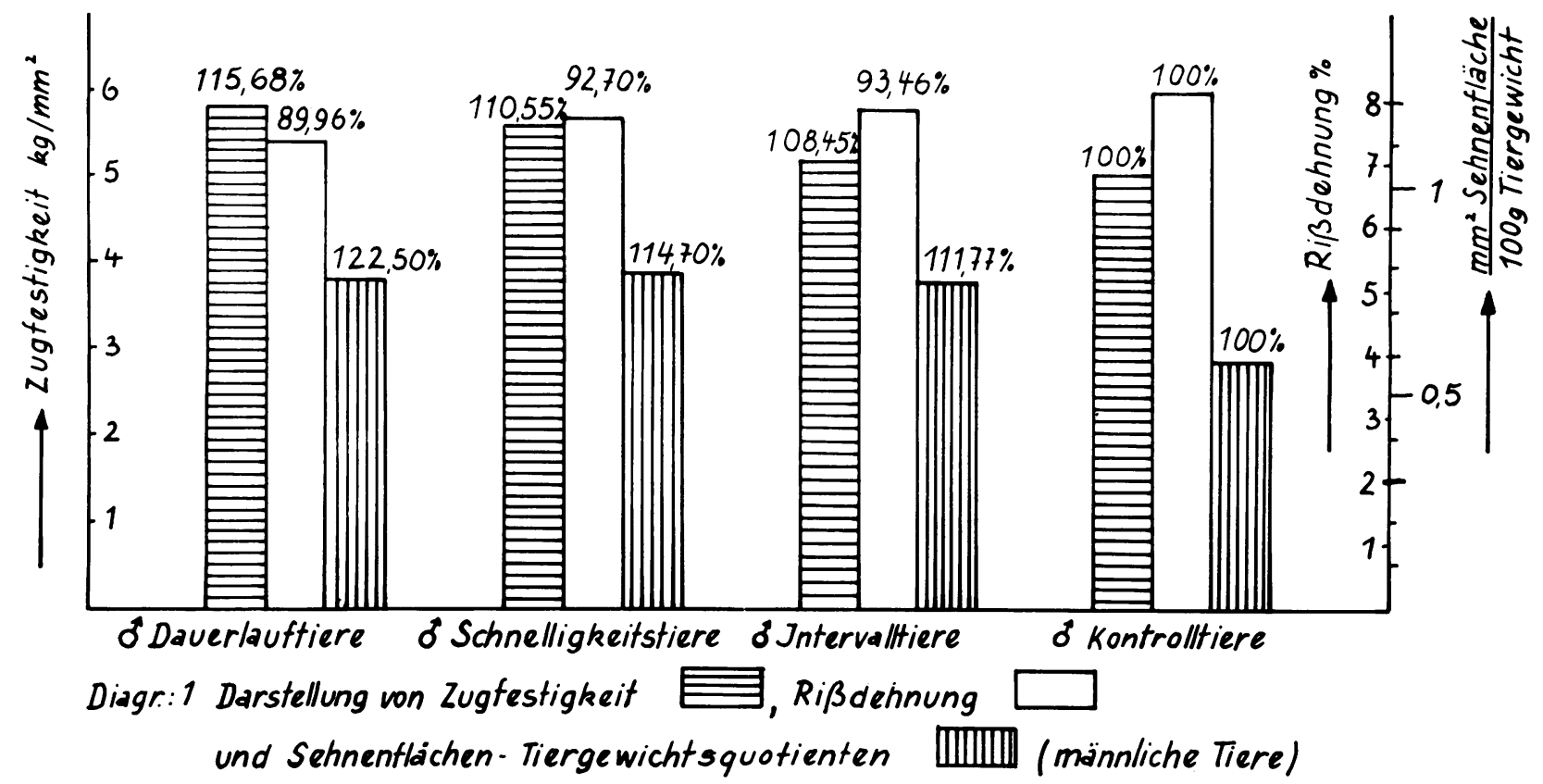

Fig. 7: The pulling stability of the trained and untrained male (fig. 7) and female (fig. 8) achilles tendons.

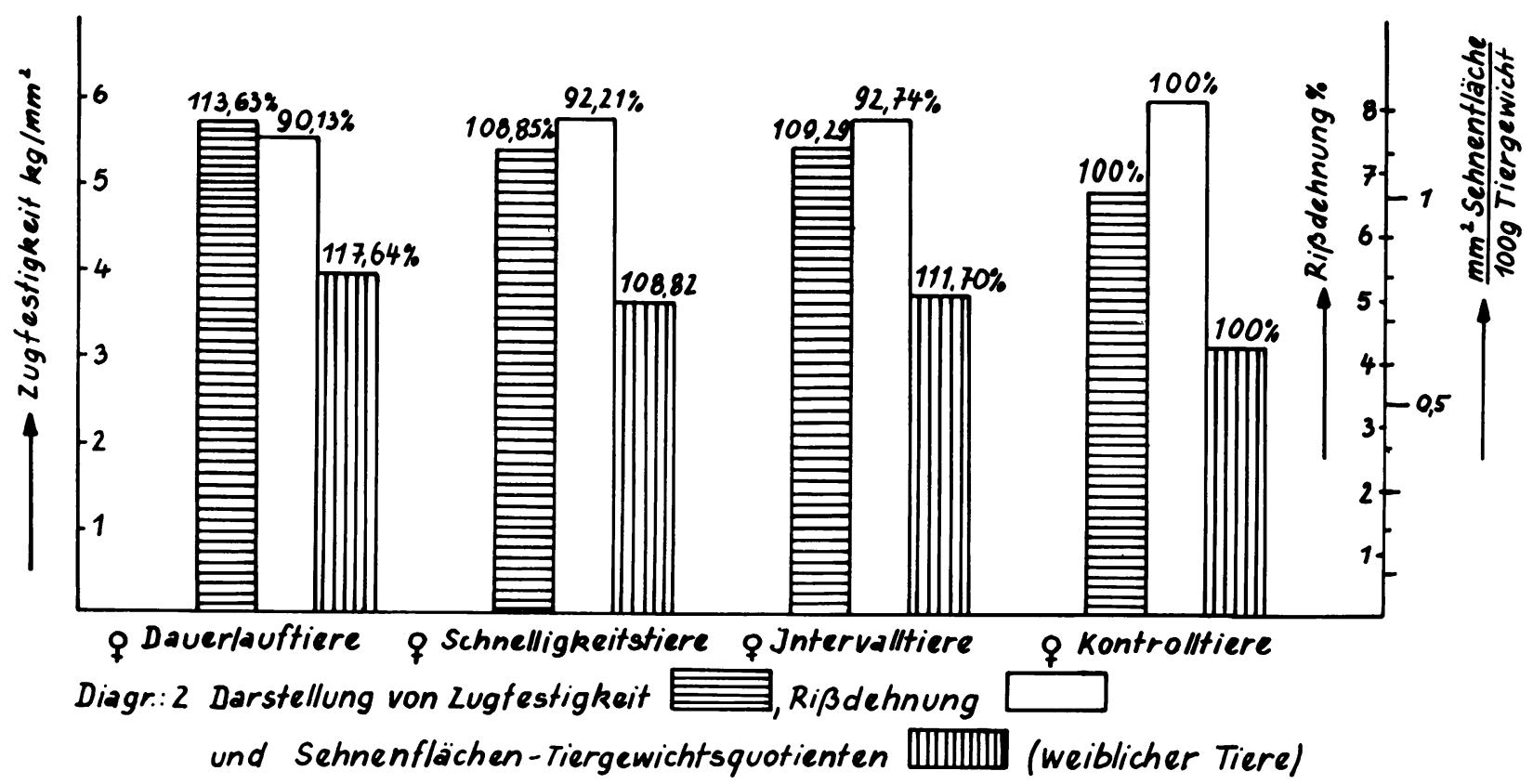

Fig. 8: The extensibility of the trained and un trained male (fig. 7) and female (fig. 8) achilles tendons.

The "tendon facet and animals' weight quotient."

evidently a consequence both of quantitative (augmentation of $\mathrm{mm}^{2}$ of tendon cross-section per $100 \mathrm{~g}$ of animal weight as the expression of hypertrophy resp. micellar reproduction) and also of qualitative (improvement of the pulling stability in $\mathrm{kg} / \mathrm{mm}^{2}$, consolidation of the micellar structure) adaptations to 


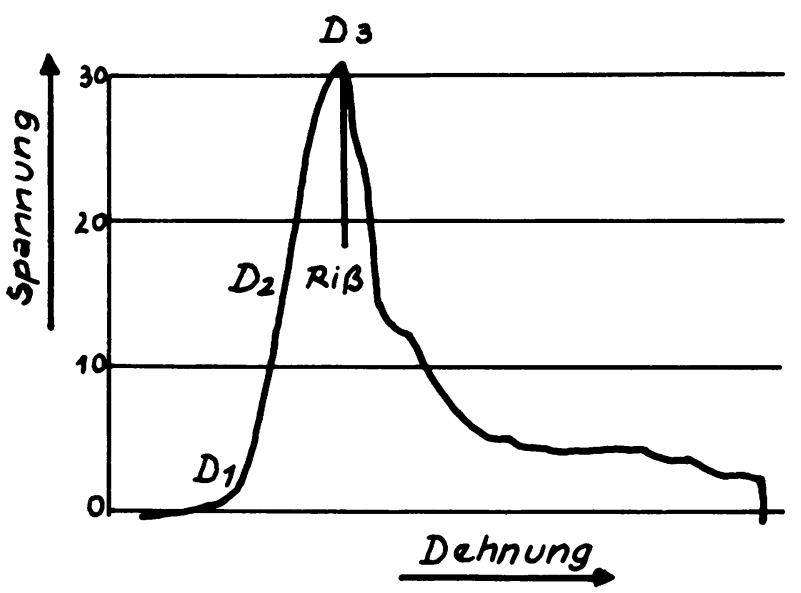

Fig. 9: Demonstration of a relatively important extension $\left(D_{1}\right)$, of a sharp rise $\left(D_{2}\right)$ and of the turning-point $\left(D_{3}\right)$ in the course of the curve; in $D_{3}$ : total rupture laccompanied by a distinct sound.)

high training loads. Here, the change in the structure of the submicroscopic field of the dense, collagen fibres occurring during the training-cycle has a special and decisive importance, changes we can trace by optical polarisation and by means of double refraction and which in the first place depend on the degree of the micellar formation. We are indebted to Rollhäuser (1954) for the knowledge that in case of the decrease of the pulling stability (by reduction of work load) there is a partial reduction of the micellar structure, and in a functionally increased work load occurs an increase, a reproduction of the micellar structure (by which we understand the solid protein chains which unite to form crystal lattice-like structures, these chains being responsible for the reception of the pulling; here the micellar order and pulling stability increase in such a degree as at the same time the water content of the tendon tissue decreases.

\section{Extensibility:}

Extensibility amounted in the male rest (control) animals on an average to 8.29 per cent. For the "interval" animals, there occurred a reduction by 6.54 per cent ( $\bar{x} 7.72$ per cent), for the "speed" animals it was 7.22 per cent ( $\bar{x} 7.66$ per cent), while for the "endurance-run" animals the reduction of the extensibility was 10.04 per cent ( $\bar{x} 7.42$ per cent). In the female rest (control) animals, the extensibility of the achilles tendon was determined to be 8.27 per cent on an average; the reduction of this initial value in the "speed" animals amounted to 6.09 per cent $(\bar{x} 7.79$ per cent), in the "interval" animals to 7.43 per cent ( $\bar{x} 7.68$ per cent), and in the "endurance-run" animals to 9.87 per cent $(\bar{x} 7.48$ per cent).

Data about the extensibility of tendinous tissue are quite different; so Triebel (1902) found a rupture extension of 4 per cent, Stucke (1950) one of 7.34 per cent, Wolpers (1944) one of 10.89 per cent, and Rollhäuser (1951) as well as Lerch (1951) one of 10 to 12.5 per cent. Our own values extending from 8.29 per cent (in control animals) and 7.42 per cent (in "endurance-run" animals) - these values being slightly higher in the female individuals, which results from the inferior pulling stability of the tissue of the achilles tendon in female rats) make clear that an increasing pulling stability is accompanied by a reduction of the extensibility, which applies evidently to some materials in technology too.

\section{Statistical significance:}

All the results of the tendon load $\left(\mathrm{mm}^{2}\right.$ of tendon $/ 100 \mathrm{~g}$ of weight of animal, $\mathrm{kg}$ of pulling stability/tendon, $\mathrm{kg}$ of pulling stability $/ \mathrm{mm}^{2}$ of tendon and extensibility in per cent) - here once more summarised in the shape of a juxta position (fig. 7 and 8) - were statistically assured (by means of the t-test), according to which the difference in all four parameters was significant between the "endurance-run" animals and the rest (control) animals of either sex.

\section{Summary}

The good general condition of the "endurance"-loaded rats, the relatively high increase of the pulling stability and of the hypertrophy of their achilles tendons under the conditions of the experiments unambiguously speak in favour of a hopeful trainability of the dense, collagen connective tissue by an "endurance' especially "strength-endurance" training, which Maurer, Zweymüller and Tappeiner (1969) confirmed by their studies on the extension of the capillary bed in the sphere of the achilles tendon and its sliding system after long and intensive running (with the indication to the intensivation of the metabolism procedures of the trained tendinous tissue), a result that corresponds to our own results obtained in experiments with animals as to the capillarisation of the spinal and heart muscles after running training of different duration and intensity (Tittel, Knacke, Brauer and Otto 1966; Tittel, Feustel, Schippel and Pieper 1970).

The practical implications for sport of our study: an achilles tendon sufficiently adapted to "endurance" esp. "strength-endurance" performances will assure high physical possibilities and will not unessentially reduce the danger of a rupture. 


\section{REFERENCES}

1. ADAMS, A.: Effect of exercise upon ligament strength. Res. Quart. 37, 163-167 (1966).

2. ALTMANN, K.: Zur Frage der Bauart und der mechanischen Beanspruchung mikroskopischer Muskelsehnen. $Z$. Anat. Entw. Gesch. 124, 57-69 (1963).

3. GREENE, E. C.: Anatomy of the rat. Hafner, New York 1955.

4. LERCH, H.: Über den Aufbau des Sehnengewebes. Morph. Jb. 90, 192-204 (1951).

5. MAURER, H., ZWEYMÜLLER, K. and G. TAPPEINER: Die Blutversorgung der Achillessehne der Ratte unter normalen und experimentellen Bedingungen. Verh. Anat. Ges. 125, 737-740 (1969).

6. RIEDE, D.: Ätiologie, Diagnose und Therapie der subkutanen Achillessehnenrisse. Beitr. Orthop. 13, 96-105 (1966).

7. ROLLHÄUSER, H: Festigkeit menschlicher Sehnen nach Quellung und Trocknung in Abhängigkeit vom Lebensalter. Morph. Jb. 90, 180-191 (1951).

8. Ibid: Untersuchungen über den submikroskopischen Bau kollagener Fasern. Morph. Jb. 92, 1-28 (1952).

9. Ibid: Funktionelle Anpassung der Sehnenfasern im submikropischen Bereich. Anat. Anz. 100, $318-335$ (1954).

10. Ibid: Der Einfluß der funktionellen Beanspruchung auf die Feinstruktur der Sehne. Morph Jb. 93, 153-169 (1954).

12. Ibid: Sehnenbelastung und Ruptur im Tierversuch. Arch. klin. Chir. 28, 212-220 (1951).

13. TITTEL, K.: Beschreibende und funktionelle Anatomie des Menschen. 5. Aufl. Fischer, Jena 1970.

14. TITTEL, K., KNACKE, W., BRAUER, B. and H. OTTO: Der Einfluß der körperlichen Belastung unterschiedlicher Dauer und Intensität auf die Kapillarisierung der Herz- und Skelettmuskulatur bei Albinoratten. 16. Weltkongr. d. FIMS, Hannover 1966. Kongr. Ber. Dtsch. Ärzte- Verlag, Köln-Berlin 1967.

15. TITTEL, K., FEUSTEL, G., SCHIPPEL, H., und K. S. PIEPER: Zur morphologischen Adaptation der Skelettmuskulatur an körperliche Höchstleistungen. 9. Internat. Anatomen-Kongreß, Leningrad 1970 (im Druck).

16. TRIEBEL, A.: Einführung in die physikalische Anatomie. Bergmann, Wiesbaden 1902.

17. WOLPERS, H.: Sehnenuntersuchungen. Virch. Arch. 312, 392-398 (1944). 


\title{
BRAIN OEDEMA AFTER SPORTS ACCIDENTS
}

\author{
K. FRANKE, Dr. med. habil \\ Dept. of Surgery, Municipal Hospital, Berlin-Pankow, G.D.R.
}

\begin{abstract}
Brain oedema due to accident in sports can result from head trauma as well as thermic stress, hypoxia after drowning, respiratory and circulatory depression.

In experiments we found brain oedema already occuring within one minute after cerebral injury.

Early and appropriate therapy of brain oedema decides prognosis in respect to survival and, later on, of brain function.
\end{abstract}

\section{Introduction}

Up to $13 \%$ of all skull and brain injuries (SBI) which are treated in hospitals result from accidents in sports. The subsequent complications of SBI may be of vital importance:

1. Disturbance of brain function, e.g. consciousness, nausea, depression of blood circulation and respiration;

2. Morphological brain lesions: oedema, contusion, laceration;

\section{Intracranial haemorrhage.}

Very often two or more of these consequences are combined. They lead to a vicious circle of intra- and extracranial complications which threatens life.

Among the effects of SBI mentioned above, oedema has the greatest importance because it occurs within one minute's time in the environment of brain haemorrhages. Also brain oedema can be caused or intensified by general hypoxia according to extracranial complications or cerebral hypoxia according to an increase of intracranial pressure.

In sports this can happen after collapse, drowning or post-traumatic depression of circulation and respiration.

Unlike hydrops of other tissues, brain oedema has some peculiarities of anatomy and function:

In the cortex there exists only a negligible extracellular space, therefore oedema is located within the cells. This intracellular hydrops elongates the distance of diffusion, disturbs the transport function of glial cells and may finally lead to a rupture of cellular membranes.
In the white matter of the brain the extracellular space is from 600 to $800 \AA$ wide and therefore oedema collects here inside and outside the cells.

The functional importance of brain oedema results mainly from lack of oxygen to the brain cells, whose tolerance towards hypoxia is the least of all tissues. Also brain oedema is an important cause in the development of raised intracranial pressure. This occurs from disproportion between the fixed volume of the skull and the increasing volume of the water-retaining brain. One result is stoppage of cerebral circulation with the final consequences of brain death and later on the individual's death. Further factors in the vicious circle of brain oedema are general hypoxia, because of circulatory and respiratory depression and local hypoxia, because of prolonged distances for cellular diffusion and increasing intracranial pressure according to the type of haematoma.

It is a widespread opinion that brain oedema after SBI is not a complicating factor before 6 or even 72 hours. We found in our experiments that oedema occurred to the injured brain within a few minutes after injury. Therefore we claim that therapy of brain oedema has to be an essential part of First Aid and also of second-aid-measures at hospital.

Efficient treatment of brain oedema not only saves life by decreasing intracranial pressure, it is at the same time a necessary prevention to late lesions of brain cells which may lead to persisting posttraumatic brain damage. The distinct characteristic of these lesions is the so-called "apallic" syndrome - a functional separation of cortex and brain stem.

The early and appropriate therapy of brain oedema is crucial to survival and to subsequent brain function. 
The modern therapy of brain oedema consists of these principles:

1. Rehabilitation of glial cells by intravenous infusion of glucose $40 \%$ - compensated by insulin -, THAM and K-Mg-Asparaginate;

2. Maintenance or recovery of cerebral microcirculation with simultaneous cellular dehydration by so-called onko-osmo-therapy (infusion of low molecular dextran and sorbitol 20\%);

3. Reduction of cholinergic components by procaine $1 \%$ - addition to solutions for infusion;

4. Artificial hypothermia in severe brain oedema in order to reduce oxygen need. 


\title{
TENDOPERIOSTITIS IN THE LATERAL FEMORAL CONDYLE IN LONG-DISTANCE RUNNERS
}

\author{
S. NILSSON, M.D. and P. H. STAFF, M.D. \\ Present address: Dept. of Physical Medicine and Rehabilitation, Os/o Kommune, \\ Ulleval Sykehus, Os/o 1, Norway
}

\begin{abstract}
Fifteen athletes were examined and treated for a complaint of pain located in the lateral aspect of the knee. All were participants in endurance events. During prolonged training and competition, pain in the knee increased and finally prevented further running. In retrospect, it was discovered that this was a common complaint among top athletes in endurance sports. Symptoms were pain in the lateral femoral condyle which began after 20-40 min. of running. When running was stopped the pain subsided, but reappeared as soon as activity was resumed. Running down hill or on the treadmill aggravated the symptoms while running uphill was often the only type of running which could be tolerated. In the fifteen athletes who were examined, the pain, after provocation tests, was located under the iliotibial tract where this passes over the femoral condyle. Some of the fibres of the iliotibial tract are attached to the condyle and during running the tract is tensed during the deceleration phase of the leg motion, just before foot strike. The load on the iliotibial tract is increased in down-hill running or in running on a treadmill, thus increasing the strain on those fibres attached to the condyle. In some instances, this strain is too severe leading to a tendoperiostitis in that area. Untreated, the condition lasts three or four months, but after steroid injection or ultrasonic treatment, the athlete can resume his activity within a few days.
\end{abstract}

\section{Introduction}

Training for competitive sport is more intense today than ever before. It is therefore not surprising that sports medicine is faced with an increasing number of athletes with "over use" injuries.

In recent years in Norway, long distance runners have consulted us because they experienced pain located in the lateral aspect of the knee while training.

The patients come for consultation in early spring and late autumn. Many doctors prescribe rest as the only therapy, however, the athlete then discovers that the symptoms reappear as soon as he resumes training.

We have studied during the past year these patients, and have tried a therapy which we find quite successful. When searching the literature we did not find any mention of this complaint. J. E. Hendryson (1946) described a bursitis of traumatic origin located in the area of the lateral collateral ligament, but neither the symptoms nor the location were the same as in our patients.

The symptoms appear in runners training for endurance events. After 20-40 minutes of running they notice pain in the lateral side of one knee. The pain is of a dull aching type, vague in the beginning, but if running is continued it soon becomes so severe that continued running is impossible.

When the symptoms are moderate, the pain is located in the lateral side of the knee, but it may spread to the upper part of the tibia and sometimes to the distal part of the thigh. As soon as running is stopped, the pain disappears. Some individuals, however, develop the symptoms quite rapidly, and experience difficulty even with walking.

Typically, running downhill often aggravates the symptoms, while running up-hill gives considerably less discomfort. Untreated, the symptoms can last for several months and thus more or less destroy a whole competitive season. This complaint is most often found among long distance runners, skiers and orienteers, but we have also treated hunters, tourists and others who experienced the complaints after walking for several hours in the mountains.

It is also common among cadets of the Army academy when they join a paratroopers course, in which they are required to run for several hours in heavy army boots to which they are not used.

During a research programme at our institute in which well-trained students were made to run for 3 hours on a treadmill, several of the participants had to stop running because of this complaint. The condition of the ground surface seems to have a certain influence since most of the cases occur in early spring and late autumn when the ground is frozen.

Skiers who experience this complaint when training before the snow falls, no longer notice these symptoms as soon as they can start training on skies.

When the patient seeks medical advice, clinical examination reveals little or nothing. When a patient comes to us with a typical story, we send the patient out 
on a run until symptoms appear. Then, upon re-examination, we often find distinct tenderness on palpation of the lateral femur condyle. We also sometimes find moderate tenderness when palpating the iliotibial tract just above and beneath the condyle. In most cases this tenderness disappears within a few hours, but after repeated training for as long as pain permits, it can last for many days. The causative mechanism of this complaint is, we believe, the strain applied to the iliotibial tract.

Running gait can, according to Slocum and James (1968) be described as a cycle of motion which starts when one foot strikes the ground and continues until the foot again strikes the ground.

Each cycle is divided into two phases:

Support phase in which the foot carries the body weight.

Forward recovery phase in which the extremity does not carry weight but advances from the trailing to the leading position.
Just a few words about this second phase. As the foot leaves the trailing position, and moves forward, the greatest extension of the hip, knee and ankle occurs. Flexion of the hip now brings the thigh forward, and at the same time we get a passive flexion of the knee. (Fig. 1 c) When the thigh is brought forward to a leading position, a rapid extension of the knee begins which is caused by the quadriceps muscle. The leg increases its forward speed and as it advances to the position of footstrike it has to be decelerated to zero velocity. (Fig. 1 c-f)

This is done by the hamstring muscles.

At the very moment of footstrike the extremity must carry weight, and the quadriceps contracts again. Both the biceps femoris and the quadriceps have fibres fastened to the lateral septum of the femur. This septum is intimately fused with the iliotibial tract, and at the very moment of footstrike the muscular contraction puts a considerable pull on this septum and thus on the iliotibial tract. (Fig. 1 f)

The iliotibial tract is regarded as a tense ligament

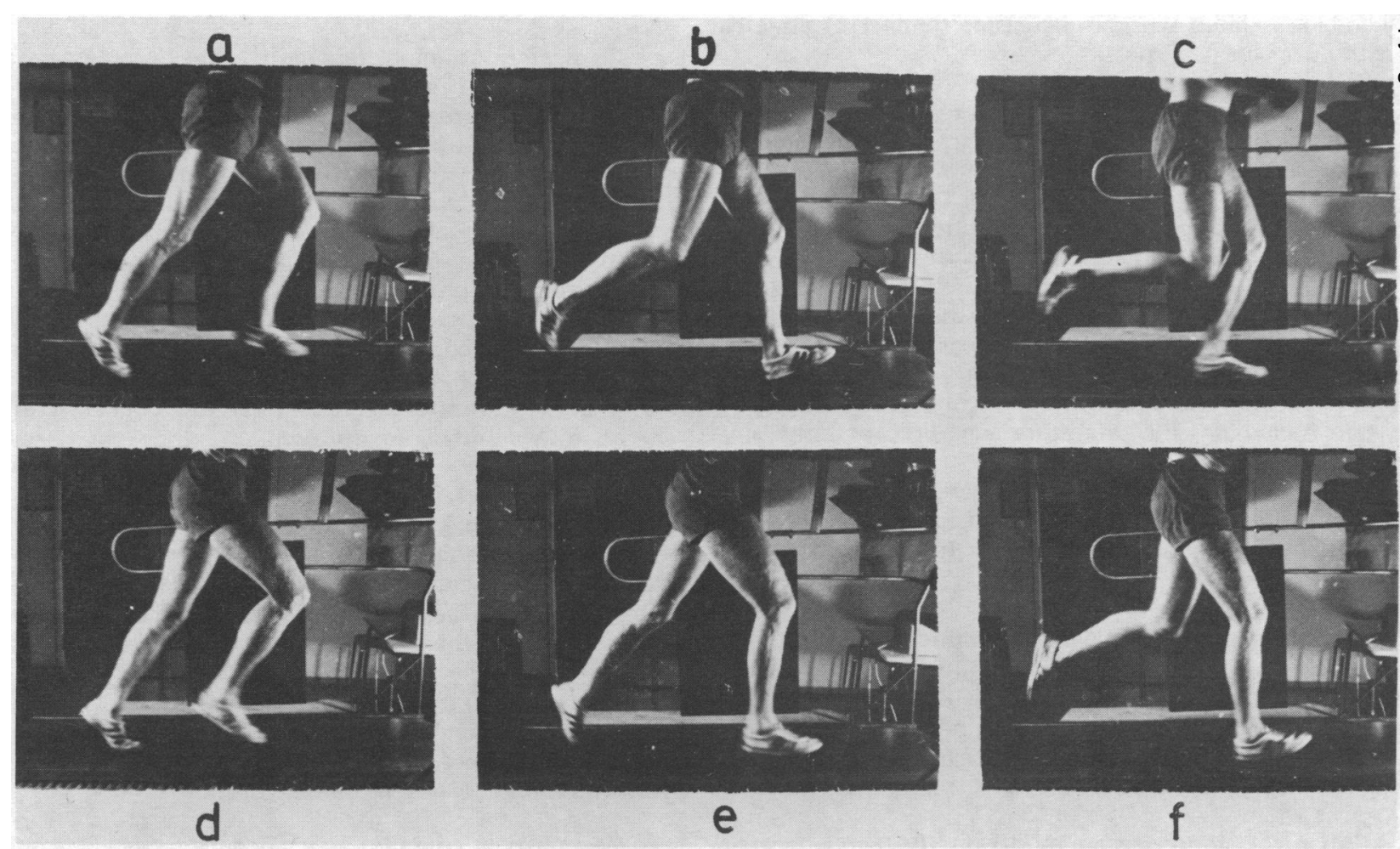

Figure 1. Shows the right extremity in the forwand recovery phase. At the very moment of foot-strike, the iliotibial tract is tensed by a simultaneous contraction of the biceps femoris and the quadriceps muscles (f) 
reaching from the iliac crest to the lateral surface of the tibia, according to Kaplan's monograph in Journal of Bone and Joint Surgery, 1958. This tense ligament glides over the femur condyle during each step, and in addition it has an insertion on the upper part of the femoral condyle.

In some runners this strain on the iliotibial tract and the periostium on the femoral condyle becomes too severe so that they develop a tenoperiostitis in this region. Running downhill, or with heavy army boots requires greater force in decelerating the leg and thus puts greater strain on the ligament and its femoral insertion which aggravates the symptoms.

\section{Treatment}

As we had good results with cortisone injections in treatment of periostitis in other regions, we began to inject lidocain and betamethasone at the point of maximum tenderness. If no point could be located, the patient was required to run until his symptoms developed and then to return for treatment. After the injection training for the next 3 days was forbidden, and for the $\mathbf{3}$ days following that the training was gradually increased up to its normal intensity. 10 patients were treated in this way, 6 became completely free from symptoms, 1 improved so that he could train as long as he avoided downhill running, and in 3 the injections had no effect.

\section{Table 1}

Results of treatment of 15 patients with tenoperiostitis of the condyle of the femur.

\section{RESULTS}

$\begin{array}{cllcc}\begin{array}{l}\text { No. of } \\ \text { patients }\end{array} & \begin{array}{l}\text { Type of } \\ \text { treatment }\end{array} & \text { Excellent } & \text { Good } & \begin{array}{c}\text { Little or } \\ \text { none }\end{array} \\ 10 & \begin{array}{l}\text { Cortisone inj. } \\ \text { Ultrasound }\end{array} & 6 & 1 & 3 \\ 5 & & 3 & 2\end{array}$

TOTAL 15

6

4

5

5 were treated first with ultrasound. 3 improved so that they could continue training, if they avoided running downhill, and 2 did not respond to treatment. Those who did not respond to ultrasound treatment later got an injection of cortisone with excellent results, and those who did not respond to treatment with injection therapy, were later treated with ultrasound with good results.

We therefore conclude that pain in the lateral aspect of the knee in long distance runners may be tenoperiostitis in the lateral femoral condyle caused by severe strain on the insertion of the iliotibial tract in that region. The treatment of choice seems to be injection of cortisone, and in those who do not respond to that treatment, ultrasound therapy may be beneficial.

\section{REFERENCES}

1. HENDRYSON, I. E.: Bursitis in the Region of the Fibular Collateral Ligament. J. Bone and Joint Surg. Vo/ 28, No. 3: 446-450, July 1946

2. SLOCUM, Donald B, and JAMES, Stanley L.: Biomechanics of Running. JAMA Vol 205, No. 11: 97-104, Sept. 9, 1968

3. KAPLAN, Emanuel B.: The lliotibial Tract. J. Bone and Joint Surg. 40-A: 817-832, 1958 


\title{
SOME RARE SITES OF OSTEOCHONDROPATHY OF THE UPPER LIMB IN YOUNG GYMNASTS
}

\author{
N. IGNATOV, D. Med. Sci. \\ Dept. of Orthopaedics and Traumatology, \\ Higher Medical Institute, Sofia, Bulgaria
}

Introduction

Osteochondropathies are a large group of illnesses characteristic of infant and adolescent ages and their aetiology is still obscure. As it is known they can affect the epiphyses of the long, short and small bones as well as the apophyses. Nowadays it is accepted that morphologically and pathophysiologically osteochondropathy represents an aseptic necrosis of the spongy bone on these parts of the skeleton. The patients age at which it usually develops corresponds to the period of appearance and rapid development of ossification in the different bones. It is noteworthy that usually the object of this process are the epiphyses, the short and small bones and the apophyses, which, due to their anatomical disposition, are under increased mechanical stress. Osteochondropathy is a rare phenomenon either in the epiphyses or apophyses which are comparatively less burdened in the ordinary life of children and youths. If however epiphyses and apophyses are set at a position of a greater and longer mechanical tension they more often become affected.

In this paper we present our observations on the development of osteochondropathy in actively sport-training children and youths in sites where it is usually rarely localised. Moreover, there are few references to these sites in the literature.

\section{Case Histories|}

We present 2 cases of osteochondropathy of the acromion-epiphysis, two cases of the olecranon epiphysis, one case of osteochondropathy of humeris-trochlea and one case of the capitulum of the radius. All our patients are students at the sport-boarding school for early sport-profiling in Sofia.

A The two patients with osteochondropathy of the acromion were 16 years old, training for gymnastics and had been doing exercises for five years. The condition of one of them is bilateral and of the other unilaterally on the right. The histories do not point to any trauma. Both patients began to feel some pain in the shoulder belt area after doing some gym exercises. On examination it has been established that a slight swelling is present in the acromion area and some pain is felt when the arm has been excessively adducted. X-ray showed typical aseptic necrosis in the ossifying nuclei of the acromion in both cases - in one of the cases it was bilateral and in the other on the right side only. A treatment was applied with ozicherit and immobilisation of the particular upper extremities. In about three months the clinical picture of the illness receded and after six months follow up X-ray showed normal bone structure of the ossifying nuclei of the acromion.

Aseptic necrosis of the acromion was first described by De Cuveland. Matzen records a case of bilateral aseptic necrosis of the acromion in a sixteen-year-old young man.

B We observed two cases with osteochondropathy of the olecranon in two schoolboys of fifteen from the same boarding school - one of them training for gymnastics for five years and the other one for wrestling for two years. Both of them began graduallyo to feel some pain during training - one of them in the area of the right elbow joint and the other on the $=$ left. Slight soft-tissue swelling was present over the affected olecranon and there was pain on pressure. $X$-ray showed aseptic necrosis of the ossifying nucleus of the two olecranons which appeared to be double in both cases. Treatment was with ozocherit* and immobilisation of the affected elbow joint. The clinical picture changed after several months, and follow up $X$-ray of the right osteochondropathy nine months later showed considerable improvement of the bony structure of the nucleus. The follow up film of the other case was taken rather early - only two months later and in spite of that a certain recovery of the bone structure of the ossifying nucleus was noticed.

We consider that the description of our cases with osteochondropathy of the olecranon is of theoretical and practical interest and moreover that so far we have not found any reports of this condition in the literature.

* wax baths

C Trochlea humerus osteochondropathy, first described by Hegemann, was observed by us in a patient of sixteen who had actively been doing gymnastics for four years. It was bilateral. The first complaint was some pain in the area of the left elbow joint when moving it. Examination showed pain on extreme 
flexion and extension as well as after pressing the area of the trochlea. The elbow joint had swollen slightly. The same complaints and clinical findings appeared in the right elbow joint later. X-ray showed bilateral aseptic necrosis of the humerus trochlea with considerable resorption of the bone substance. Treatment was with ozocherit and immobilisation of the elbow joint. A few months later symptoms receded. Follow up film of the left arm taken after ten months showed a definite recovery of the nucleus of the trochlea-epiphysis. The right elbow film after seven months showed signs of recovery of the epiphysis of the trochlea.

D In the case with a right side osteochondropathy of the right acromion epiphysis described above we also found an osteochondropathy of the capitulum of the right radius. This was first described by Hegemann. Besides the symptoms mentioned above our patient had some pain in the area of the capitulum of the right radius on pressure and extreme pronation and supination of the arm were accompanied by pain in the elbow joint due to the affected acromion.

\section{Conclusions}

The observations on these cases of osteochondropathies of unusual localisation are enough for us to accept that the condition is related to early active gymnastics as almost all our patients are gymnasts profiled quite young and gymnastics involves heavy mechanical burdening of the shoulder and elbow joints. We feel that these conditions relate to the character of the exercises and sometimes after heavy injuries the vascular and nervous apparatus of the epiphysis may be affected which leads to disturbances in ossification.

\section{Summary}

Clinical descriptions are given of osteochondropathies of the shoulder and arm in young gymnasts.

\title{
TRAUMATIC ARTHRITIC LESIONS IN THE HANDS OF BOXERS
}

\author{
M. LIOUNGAS, M.D., and N. TRIANTAFYLLOU
}

1 Metaxa, Glyfada, Greece

\begin{abstract}
Fifteen cases of athletes who were systematically exercised in boxing for an average of 4-7 years approximately have been studied. These athletes have fought many times in National or International games and were under a heavy daily training in boxing. The age of the group was 17 to 26 . Another group of 20 males of the same age but not having any relation to boxing has also been studied for comparison.
\end{abstract}

A high incidence of synovitis, periostitis or arthritis has been discovered from study of the hands of the athletes. The authors believe that the development of the above-mentioned lesions had a direct relationship to boxing, probably due to the frequent trauma during training.

The authors make some recommendation for the prevention of these and discuss briefly their method of treatment. 


\title{
MECHANICAL OBSTRUCTION OF VERTEBRAL ARTERIES DURING HYPEREXTENSION OF NECK
}

\author{
W. NAGLER, M.D., F.A.C.P. \\ Department of Rehabilitation Medicine, The New York Hospital-Cornell Medical Center, \\ 525 East 68th St., New York, N.Y. 10021
}

Associate Professor of Medicine, Cornell University Medical College.

\section{Introduction}

The aggravation of symptoms in cervical radiculopathy by hyperextension of the cervical spine is a well-known phenomenon and familiar to physicians whose sphere of interest is in neuroskeletal problems. While an acute temporary insufficiency of the basilar artery, caused by blood flow impairment of the vertebral arteries, is a well-established syndrome ${ }^{r}$, obstruction of the vertebral arteries with severe neurological sequelae after calisthenics is a rarely reported event. In temporary basilar artery insufficiency one assumes it comes from an obliteration of vertebral artery flow by contraction of the longus colli and scalenus muscles at the transverse foramen of the sixth cervical vertebra. ${ }^{2}$ These muscles are contracted when the head is turned laterally and upwards. Also inuscle spasms in the suboccipital region were reported as having caused a compression of the vertebral arteries at the level of the first cervical vertebra. ${ }^{3} \mathrm{~A}$ hypoplastic contralateral vertebral artery, which alone does not adequately supply the basilar artery circulation, is often present in these cases of temporary basilar artery insufficiency which may be caused by headturning. As shown in vertebral arteriograms, the right and left vertebral artery may often vary strikingly in the caliber of lumen. Such asymmetries do usually not cause any symptoms. In contrast with the relative limited attention given to headturning and vertebral artery insufficiency, a definite relationship has been proposed between vertebral artery impairment and extensor-flexion trauma at the atlanto-vertebral junction. ${ }^{4 / 5} / 6$ Reports of insufficiency due to extra-luminal factors such as scar tissue, ${ }_{7}$ soft tissue bands, $8 \%$ osteoarthritis and osteophytes ${ }^{10}$ have already found their way into literature.
\end{abstract}

ABSTRACT

Four persons, ranging in age from 18 to $\mathbf{5 5}$ years, suffered spinal cord or cerebellar damage immediately following the performance of a calisthenic discipline. One common feature of the various exercise disciplines was forceful hyperextension of the cervical spine. The neurological deficit pointed toward a blood flow obstruction of the vertebral arteries. Two of the four patients suffered cerebellar infarction and two occlusion of the anterior spinal artery. Three of the patients showed abnormalities such as a narrowed foramen magnum, tortuosity of a vertebral artery, or osteoarthritis. All four patients were symptom-free prior to the onset of the neurological deficit. The occurrence of a catastrophic neurological deficit after vertebral artery occlusion seems rare. The risk of such a catastrophic deficit seems to be increased in patients with vascular and bony abnormalities in the cervical region.

\section{Applied Anatomy}

The following topographical comments should serve to clarify the mechanism which leads to an obstruction of the blood flow. The vertebral artery usually arises from the subclavian artery and travels up the cervical spine traversing in the foramina transversia of the upper six vertebrae. The vertebral artery, supported in rigid bony rings in the transverse processes, is inevitably moved with every movement of the spine and head. In going from the axis to the atlas, the vessel passes laterally. Turning anteriorly it goes through the atlanto-occipital membrane into the posterior fossa by the way of the foramen magnum. Shortening of the cervical column by damage of the discs, which is followed by distortion of the intervertebral joints may lead to sinuosity and compression of the vertebral arteries without necessarily causing degenerative changes in the wall of these arteries. ${ }^{11}$ These distortions increase the chance of a reduced blood supply to the arteries branching off these vessels.

The neurological deficit as related to vertebral artery blood flow blockage is caused by damage to the central nervous structures which receive the main blood supply from branches of these vessels. Two branches of these vessels unite anterior to the pyramids to form a single descending anterior spinal artery. Its continuity is to a great measure a function of the branches anastomosing between the anterior.spinal artery and some anterior radicular arteries. It provides midline rami to the lower medulla and gives off sulcal arteries that enter the anterior median fissure to supply a portion of the spinal cord. The portions supplied are the anterior and lateral horns, the anterior and lateral funiculi, the anterior and 
lateral pyramidal tracts, the central gray area, and the base of the posterior horns. Another somewhat larger branch which also takes it origin from the vertebral arteries, is the right and left posterior inferior cerebellar. artery which supplies the more caudal portions of the cerebellum. With the exception of the ventral portion of the crux cerebri, the blood supply of the medulla, pons, mesencephalon, and cerebellum is derived from the vertebro-basilar artery system. 12

\section{Case Histories}

Four patients suffered a severe neurological deficit following calisthenics. The neurological deficit was of a nature implicating damage of the neuro-anatomical structures supplied by vertebro-basilar artery blood flow. The features common to all four persons were:

1. Free of major symptoms prior to the onset of the meurological deficit.

2. The exercise discipline which they performed just prior to the onset of the severe neurological deficit called for a forceful dorsiflexion of the cervical spine.

3. The neurological deficit was such that it correlated with dysfunction of the spinal cord and cerebellar areas nourished by the vertebral basilar artery system.

Fig. 1

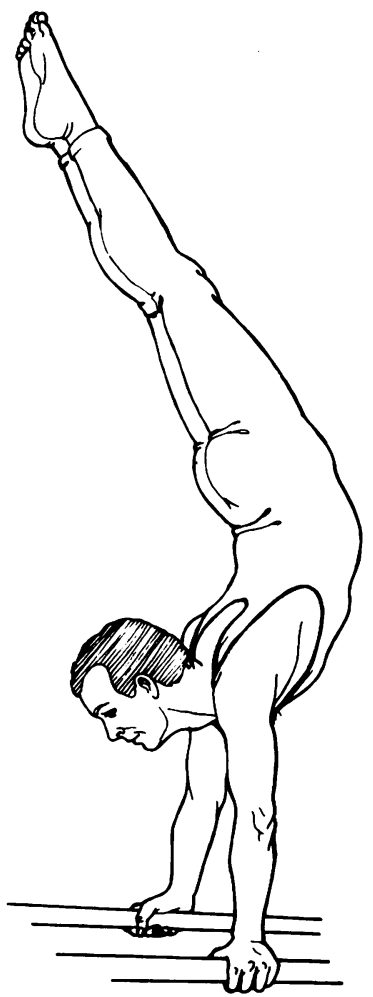

A. The first patient, an 18-year old man, high school student, who was a well-versed gymnast, performed a handstand in the parallel bars (Fig. 1). He forcefully threw his head backward to maintain balance. Suddenly he felt weak in arms and legs. His arms gave way and he landed on the mattress feet first. The coach thought the gymnast had suffered a fainting spell and he therefore was put under a cold shower. The patient states that at no time did he lose consciousness. The strength in upper and lower extremities did not return. Shortly afterwards he was admitted to the hospital where neurological examination showed a complete flaccid paralysis with a motor level at C-5 and a sensory level at T-4. The deep tendon reflexes were absent. BP 120/80. Cranial nerve function was intact. The vital capacity was 2 liters. Vibratory and position senses were intact. CBC, electrolytes, myelogram, and vertebral arteriogram were within normal limits. No cord compression was found. Babinski responses were present bilaterally. There was no impairment of urinary or bowel control. Over a two-month time hyperreflexia and spasticity in the upper and lower extremities gradually set in. Eighteen months after the onset of the quadriplegia the patient was still wheelchair-bound in spite of comprehensive rehabilitation efforts.

B. A 55-year old lawyer, also suffered a neurological deficit which is usually attributed to an impairment of the spinal cord area nourished by the anterior spinal artery. During most of his adult life the patient did not show any inclination for any strenuous physical activity. He smoked cigars and had no complaints short of headache and occasional giddiness when he turned his head fast. At age 54, becoming concerned about his health and posture, he engaged in calisthenics. The patient was lying in a prone position on a table, legs fixed, bent downward at the lumbar region over the edge of the table. He had his hands locked behind the head. He tried to come up to the horizontal, the neck maximally dorsiflexed (Fig. 2). He suddenly felt dizziness, heaviness and weakness in arms and legs. He was helped down from the exercise table. He was unable to ambulate and could not lift his arms.

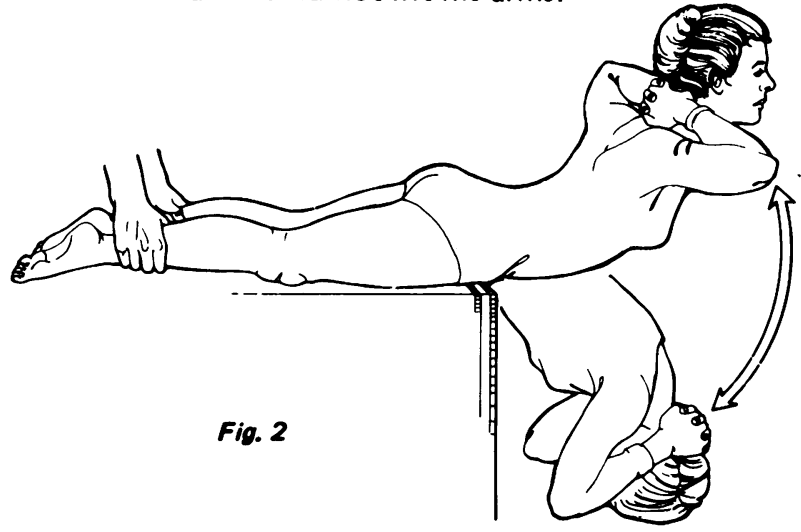


Physical examination after admission to the hospital showed a motor level at C-5 and a sensory level at C-4. There was no impairment of vibratory or position senses. $X$-rays of the cervical spine did reveal some abnormality in C1-C2 and extensive hypertrophic osteoarthritic changes. A small foramen magnum was found on the myelogram. Multiple cervical laminectomies were performed. The patient showed some gradual recovery and was able to ambulate with platform crutches one year later.

Unfortunately, at a later date, the patient received some therapeutic regimen while out of the country, which consisted of manipulation of the cervical spine. The neurological deficit increased after one of these therapeutic manipulations. Two years after the onset of the original paralysis and nine months after the second episode the patient can ambulate slowly with a walking aid on level ground. There is spasticity and hyperreflexia in all four extremities.

While these two patients apparently suffered an ischemia of the spinal cord area supplied by the anterior spinal artery, two of the patients suffered impairment in the cerebellum, supplied by the cerebellar arteries.

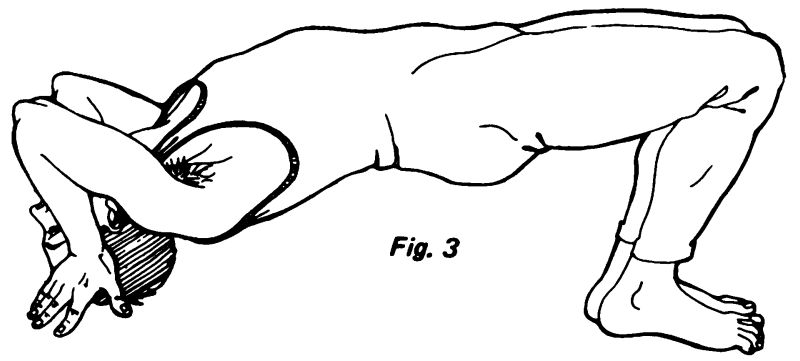

C. A 28-year old woman, Yoga enthusiast, performed the so-called "bridge" or "back pushup". This specific discipline consists of hyperextension of the cervical spine, the head maximally dorsiflexed serving as a support on one end and the heels and soles on the other end of the "bridge" (Fig. 3). While maintaining this position for about $\mathbf{2 0}$ to $\mathbf{3 0}$ seconds, she suddenly felt a severe throbbing headache. She had some difficulty getting off the floor. After she was helped into a standing position, she was unable to ambulate without assistance. The neurological examination at the hospital revealed nystagmus to the left, dysmetria in the left upper extremity and left lower extremity. hemianesthesia on the right, and a left Horner's syndrome. She also had a tendency to fall to the left. A vertebral arteriogram did show narrowing of the left vertebral artery between $\mathrm{C} 1$ and $\mathrm{C2}$ (Fig. 4) and displacement of the crebellar arteries (Fig. 5). In addition a brachial arteriogram showed bowing rostrally of the distal portion of the left superior cerebellar artery suggesting a displacement by a mass in the left cerebellar hemisphere (Fig 5).

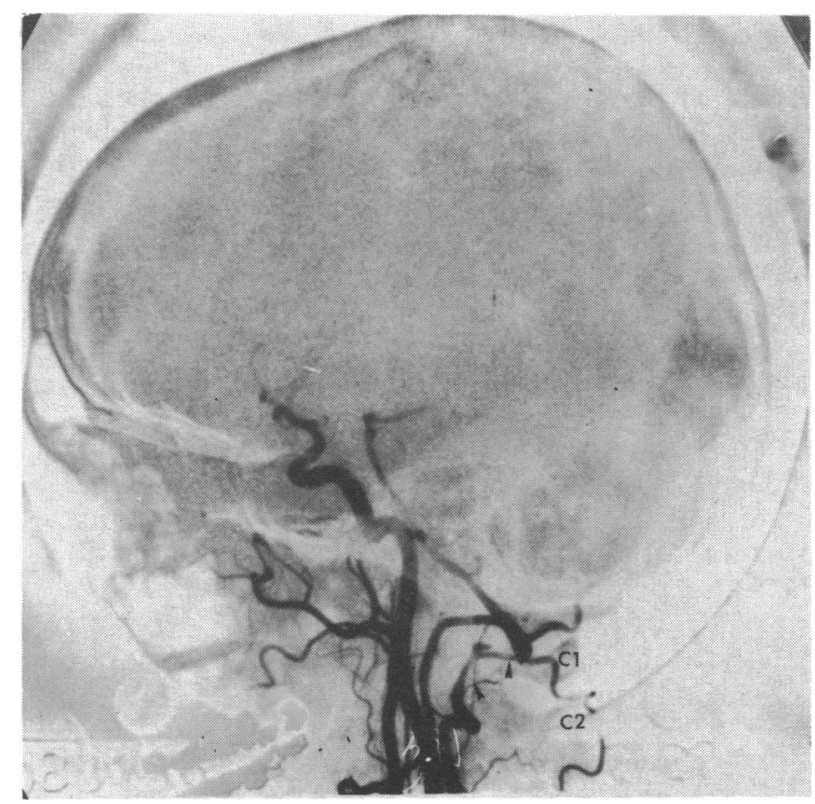

Fig 4 Vertebral Arteriogram Arrows indicate a narrowing of the left vertebral artery at the point where it passes from C2 to C1, and around the atlas.

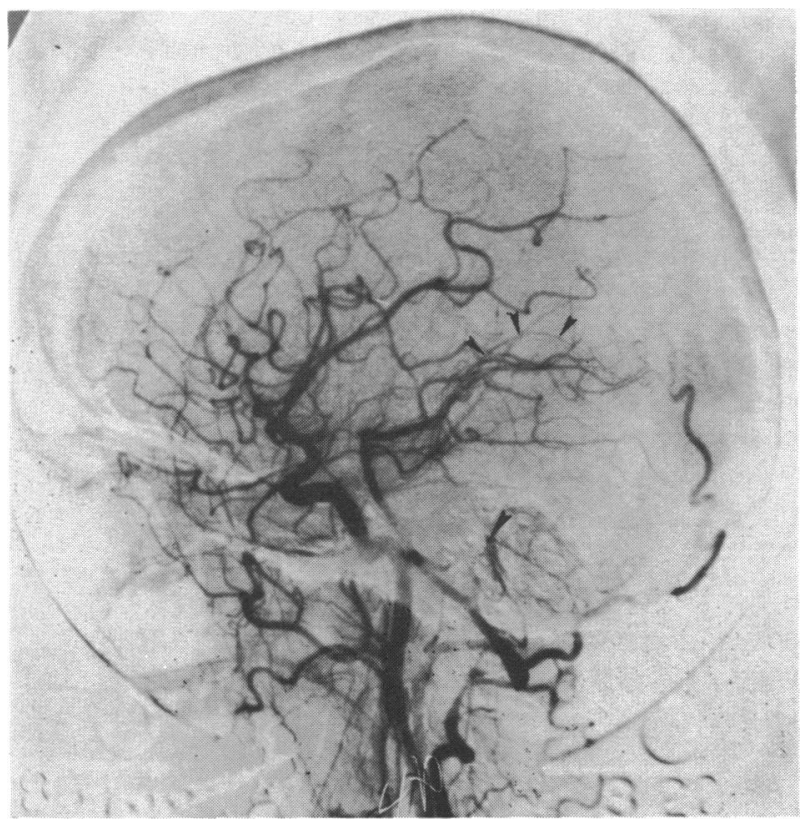

Fig. 5 Brachial Arteriogram Angulation of left posterior inferior cerebellar artery (one arrow). Bowing and displacement rostrally of the loft superior cerebellar artery (three arrows).

A craniotomy was performed five days after the onset of the neurological deficit. An ischemic infarct with secondary hemorrhages was found on surgical exploration in the left cerebellar hemisphere. The patient received an 
extensive rehabilitation programme. Two years after the onset she is able to walk with a broad-based gait. Dysmetria in the left upper extremity and the Horner's syndrome are still present.

D. A 51-year old man with coronary artery disease on electrocardiographic examination, was used to playing tennis and walking briskly. Occasionally he felt some pain and heaviness in his chest. He was informed by his physician that his blood pressure was somewhat elevated. He was placed on antihypertensive medication.

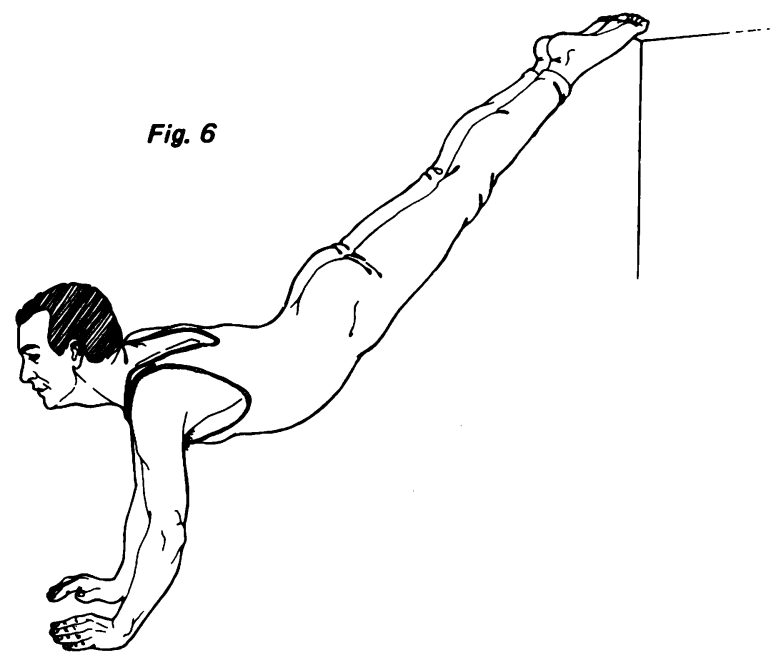

One day he felt particularly well and after a brisk two-mile walk with occasional intermittent short-distance running he topped his activities with some pushups. With the legs elevated and the head maximally dorsiflexed, he started to perform pushups (Fig. 6). He suddenly felt lightheaded and dizzy and his vision became impaired. He was able to get up but had a tendency to fall to the left. The people accompanying him noticed some changes in his speech. He also had some swallowing difficulties. He was brought to the hospital and the neurological examination did show dysmetria in the left upper and left lower extremities. He was unable to walk on stairs or turn fast. His blood pressure was 180/100 and his blood chemistry was normal. X-rays of the cervical spine showed extensive hypertrophic changes with spurs and ridges. A carotid arteriogram revealed patent carotid arteries. A vertebral arteriogram showed some narrowing of the lumen in the left vertebral artery at C5-C6 level. After one year of intensive rehabilitation, including speech therapy, the patient was able to return to his previous work as a public relations consultanit.

\section{Discussion}

The acute onset of the neurological deficit and its characteristics and distribution clearly support a vascular occlusion in the four patients presented, two with cerebellar lesions and two with acute myelopathy. Most of the cases of vertebral artery obstruction reported in the literature did show some abnormalities in the cervical spine or in the corresponding arterial system in addition to a specific trigger factor like manipulation or external trauma force to the cervical spine. Three out of the four presented patients did show such abnormalities. Only in one patient (Pt. A) did four-vessel arteriography and myelogram fail to show any abnormality.

Thrombosis of the vertebral arteries after injuries to the neck by external forces is not unknown.

Isolated cases of vertebral artery occlusion with a subsequent thrombosis of the inferior cerebellar artery have found their way into the literature. Such occlusions were attributed to chiropractic manipulation and the fracture of a cervical vertebra. ${ }^{19}$ ? 20

Exercises which require a forceful dorsiflexion of the cervical spine are performed frequently by many persons, but it is rare to have vertebral artery occlusion with a catastrophic neurological deficit as a sequela. The explanation probably lies in the anatomy of the vascu!ar supply. The abundance of collateral circulation with a manifold of variation, though, may maintain the blood supply. For the spinal cord it may come from some anastomosing radicular arteries.

The two patients (A and B) who suffered an acute myelopathy characteristic of anterior spinal artery occlusion, may not have had sufficient flow from some of these radicular arteries to substitute the blood supply.

The same may be applicable to the two patients (C and D) whose exercise performance was followed by a cerebellar infarct. When forceful dorsiflexion of the cervical spine caused occlusion of the vertebral arteries, the flow from the circle of Willis may not have sufficed to maintain nourishment to all areas of the cerebellum.

\section{Conclusion}

The forceful hyperextension of the cervical spine followed by a catastrophic neurological deficit suggests a strong causal relationship between the two.

The risk of vertebral artery occlusion by forcefui hyperextension seems to increase with the presence of some vascular abnormalities and osteoarthritic changes in the cervical spine.

Frequent as these changes are in the middle age group, routine physical examinations and multiple screening tests are not directed toward detecting such 
changes.

The therapeutic value of the specific exercises the patients presented performed is not sufficiently substantiated to justify the potential risk. Vertebral artery occlusion or ischemia resulting in a neurological deficit of such severity as to cause cerebellar infarction and quadruparesis is rare, but it is an indicator of the potential hazard of forceful hyperextension of the neck.
A physician who has to give guidance in exercise programmes should be cautious in recommending exercises of this nature to middle-aged persons.

\section{Acknowledgements}

The illustrations of the arteriograms were provided by Dr. Michael Deck, Associate Professor of Radiology, Cornell University Medical College.

\section{REFERENCES}

1. HUSNI, E. A., BELL, H. S., STORER, J.: Mechanical Obstruction of the Vertebral Arteries. J.A.M.A. 196: 475-478, 1966.

2. WAGNER, M., KTIZEROW, E., TAITEL, A.: Vertebral artery insufficiency. Arch. Surg. 87: 885-886, 1963.

3. COBURN, D. F.: Vertebral artery involvement in cervical trauma. Clin. Orthop 24: 61-63, 1962.

4. JACKSON, R.: The cervical syndrome. 2nd ed, publication 334, American Lecture Series. Monograph in Bannerston Division of American Lectures in Orthopedic Surgery. Springfield, III. Charles Thomas 1958, pp. 51-52.

5. POWERS, S. R. Jr., DRISLANE, T. M., NEVINS, St.: Intermittent vertebral artery compression: A new syndrome. Surgery 49: 257-264, 1961.

6. BAUER, R., SHEEHAN, S., MEYER, J. S.: Arteriographic study of cerebrovascular disease. II. Cerebral symptoms due to kinking, tortuosity, and compression of carotid and vertebral arteries in the neck. Arch. Neurol. (Chic) 4: 119-131, 1961.

7. POWER, S. Jr., DRISLANE, T. M., LANDOLI, E. W.: The surgical treatment of vertebral artery insufficiency. Arch. Surg. 86: 60-64, 1963.

8. FORD, F. R., CLARK, D.: Thrombosis of basilar artery with softening in the cerebellum and brain stem due to manipulation of neck: A report of two cases with postmortem examination. Bull. Hopkins Hospital 98: 37, 1956.

9. PRATT-THOMAS, H. R., BERGER, K. E.: Cerebellar and spinal injuries after chiropractic manipulation. J.A.M.A. 133: $600,1947$.

10. SMITH, R. A., ESTRIDGE, N. N.: Neurologic complications of head and neck manipulations. J.A.M.A. 182: 525, 1962.

11. VIRTAMO, P., KIVALO, E.: Impression on the vertebral artery by deformations of the uncovertebral joints. Acta. Radiol.Stockh. 48: 140-142, 1957.

12. TRUEX, R. C., CARPENTER, M. B.: Blood supply of the central nervous system. Human Neuroanatomy, 6th ed. Baltimore, The Williams and Wilkins Company, pp. 59-88.

13. SIMEONE, F. A., GOLDBERG, H. I.: Thrombosis of the vertebral artery from hyperextension injury to the neck. J. Neurosurg. 29: 540-544, 1968.

14. CARPENTER, S.: Injury of neck as cause of vertebral artery thrombosis. J. Neurosurgery 18: 849-853, 1961.

15. GREEN, D., JOYNT, R. J.: Vascular accidents to the brain stem associated with neck manipulation. J.A.M.A. 170: 522-524, 1959.

16. KUNKLE, E. C., MULLER, J. C., ODOM, G.L.: Traumatic brain stem thrombosis: Report of a case and analysis of the mechanism of injuries. Ann. Int. Med. 36: 1329-1335, 1952. 
17. PRIBEK, R. A.: Brain stem vascular accident following neck manipulation. Wis. Med. J. 62: 141-143, 1963.

18. SCHNEIDER, R. C., CROSBY, E. C.: Vascular insufficiency of brain stem and spinal cord in spinal trauma. Neurology Minneap. 9: 643-656, 1959.

19. SCHWARZ, G. A., GEIGER, J. K., SPANO, A. V.: Posterior inferior cerebellar artery syndrome of Wallenberg after chiropractic manipulation. Arch. Intern. Med. 97: 352-354, 1956.

20. SVECHTING, R. L., FRENCH, L. A.: Posterior inferior cerebellar artery syndrome following a fracture of a cervical vertebra. J. Neurosurg. 12: 187-189, 1955. 


\title{
SETTING SKI RELEASE BINDINGS
}

\author{
H. C. W. STOCKBRIDGE, M.A.
}

Civil Aviation Authority, London. Member of the Technical Committee of the Ski Club of Great Britain.

\section{Introduction}

Ideally ski release bindings should be designed, tested and set. These three stages require to be carried out by three independent groups of people. Firstly the designer produces a device which will release before a leg is strained or broken. Secondly consumer research compares available devices. Thirdly the user sets his binding in a practical way before he begins to ski, and may subsequently readjust it when skiing.

This paper considers each of these three stages briefly and in turn.

Part 1 Leg Strength - the designer.

\section{Method and Results}

Data on sex, age, size of leg and the breaking points of legs were obtained from Asang (1968). These data had been obtained by breaking legs in calibrated test rigs and are, to date, the best data available to the author. It must, however, be said that more data would be welcome, since there are only 12 female and 33 male subjects, many of whose ages are somewhat high. The bones of older subjects might be supposed to break more easily than those of the young so that the findings are probably biassed in the direction of "failing safe".

Regression equations were computed from these data and are given below.

$$
\begin{array}{ll}
N & \\
33 & \text { Men only } Y=-2177.92+45.9812 x_{1} \\
12 & \text { Women only } Y=833.132+0.19613 x_{1} \\
45 & \begin{array}{l}
\text { Men and women } Y= \\
\text { combined }
\end{array} \\
\text { where } & \\
Y & =\text { torque required to break the leg in kp.cm } \\
& x_{1}=\text { width of the leg in } \mathrm{mm} \text { at the top of the } \\
\text { shin. } \\
x_{2}=\text { age of the leg in years. }
\end{array}
$$

Statistical analysis shows that predictions for the strength of legs might be made for Men from the first equation, and for Women from the third.

Since $r_{1.23}$ for the second equation is not statistically significant there appears to be no basis for using the second equation to provide a table for predicting the strength of Women's legs, $\left(r_{1.23}=0.37\right.$, $\mathrm{N}=12$, not sig.).

The error of estimate was calculated for Men $(N=33)$

$$
S_{1.23}=19.05
$$

The error of estimate for both Men and Women combined $(N=45)$ was found to be

$$
S_{1.23}=19.40
$$

Part 2 Comparing bindings - the tester.

Readings on the torque required to open a binding were obtained using a torque wrench. Three designs of bindings were tested using two examples of each design Bindings were opened in a clockwise and counter clockwise directions at various settings. The results were submitted to analysis of variance. The torque on "good" binding should vary only with the setting: Sensitivity of adjustment was also considered. Since these bindings we used for the tests are now obsolete

$\begin{array}{llll} & r 1.23 & P< & \\ -13.8504 x_{2} & 0.82 & 0.1 \% & \text { equation 1 } \\ -7.24092 x_{2} & 0.37 & \text { NS } & \text { equation 2 } \\ -12.5410 x_{2} & 0.59 & 0.1 \% & \text { equation 3 }\end{array}$

only the method is described here.

Part 3 Setting bindings - the user

\section{Introduction}

Using the estimates of leg and binding "strength" and of its variability it remains to indicate how these findings can be used to set a particular binding in a formal way, off the snow.

\section{Method}

A skier (male, aged 20 , shin width $75 \mathrm{~mm}$, binding Z) is estimated as having a leg strength of $995 \mathrm{kp} . \mathrm{cm}$ (equation 1). We subtract $40 \mathrm{kp} . \mathrm{cm}$ (2 s.d.) from this figure to allow a margin of safety, giving $955 \mathrm{kp} . \mathrm{cm}$ as our estimate. The binding must release below this figure. 
The s.d. of setting for binding $Z$ is found to be 53 $\mathrm{kp} . \mathrm{cm}$. The binding must be set with a torque wrench so that the mean of the setting opening torque is approximately $106 \mathrm{kp} . \mathrm{cm}$ below $955 \mathrm{kp} . \mathrm{cm}$, our leg strength estimate, i.e. $855 \mathrm{~kg} . \mathrm{cm}$, to allow a high probability that the leg will remain unbroken in a crash.

\section{Discussion}

More data on legs and bindings would allow closer estimates on their "breaking" points.

It is possible that a more sophisticated statistical approach would allow less stringent criteria than 2 s.d. margins of safety for leg and binding estimates. Both means could be graphed as standard normal deviates and a cutting point approximated.
Informal adjustment on the snow, should follow the method of successive approximation, from the lowest setting by quarter turns of the torque setting, control, until a point appropriate to all the conditions of use has been reached.

\section{Acknowledgements}

The author would like to acknowledge the invaluable assistance of Mrs. C. L. Y. Briscoe in obtaining test data on bindings and of $\mathrm{Mr}$. L. M. Croton in translating original papers from the German. He would also like to thank Mr. L. Zurick and Mr. G. D. Samuel for their statistical help and advice, and, finally Dr. K. Tyler and Mr. P. Henry for stimulating discussions.

\section{REFERENCE}

ASANG, E. (1968) Ein sportärztlicher Beitrag zur Sicherheit beim Skilauf Europa - Sport, 1664-1665. 


\title{
LOW BACK PAIN IN DIVERS
}

\author{
W. GROHER, M.D. \\ 1 Berlin 33, Clayallee 229/233, Germany
}

\begin{abstract}
Enquiries conducted in a group of $\mathbf{7 0}$ diving board divers showed an average frequency of dorsal pains in $50 \%$. Young people engaged in this type of sport complained of these pains to a much lesser degree. Clincial investigation of 32 active divers showed a clear limitation of the lumbar portion of the spine in 22 cases, and the reclination at the dorso-lumbal portion was also clearly limited.

$X$-ray pictures of the lumbar portion of the spine in its functional position confirmed these clinical findings.

The X-rays showed, even in young divers, considerable degenerative changes of the small spinal joints as well as signs of arthrosis of the spinal processes in the sense of "kissing spines". An abundance of fissure-formations in the region of the interarticular portion with the typical sliding processes of a spondylolisthesis was very conspicuous.

Fatigue fractures in persistent microtraumata could be a possible explanation for these changes. These microtraumata can be accounted for by the mechanics of the dive, in that the main strain on the lumbar portion of the spine does not take place on diving from the tower or board, but on entering the water after an imperfectly executed dive. In these cases jerky distortions (particularly of the lumbar portion of the spine) occur in the sense of hyperflexion and hyperextension.
\end{abstract}

\section{RÜCKENSCHMERZEN UND RONTGENOLOGISCHE VERÄNDERUNGEN DER WIRBELSAULE BEI KUNST- UND TURMSPRINGERN}

\author{
Orthopädische Klinik u. Poliklinik der Freien Universitat Berlin
}

Das Thema "Rückenschmerzen und röntgenologische Veränderungen der Wirbelsäule bei Kunst- und Turmspringern" beinhaltet bereits eine Aussage darüber, daß derartige Veränderungen gefunden und diese auf den Leistungssport bezogen bzw. in einen ursächlichen Zusammenhang mit diesem gebracht werden.

Mir ist bewußt, daß ich mit dieser Behauptung, die ich im Laufe dieses Vortrages zu beweisen versuche, im Gegensatz zu vielen Autoren stehe, die dem Leistungssport generelle Schädigungen der Wirbelsäule nicht anlasten wollen.

Dabei wäre nach Schluß des Vortrages darüber zu diskutieren, inwieweit den röntgenologisch nachgewiesenen Veränderungen ein effektiver Krankheitswert zuzumessen ist; denn wir alle wissen, daß lediglich auf Grund eines oder mehrerer Röntgenbilder ohne die entsprechende klinische Symptomatik nicht in allen Fällen eine Erkrankung diagnostiziert werden kann, andererseits aber auch krankhafte Veränderungen des Skelettsystems ohne röntgenologische Veränderungen vorliegen können.

In den hier vorliegenden Fällen handelt es sich aber sicher nicht nur um knöcherne Veränderungen, sondern in ebensolchem Maße um Veränderungen des gesamten Bewegungssegmentes mit den hieran beteiligten Zwischenwirbelscheiben, Bändern und kleinen Wirbelgelenken.

Bereits die Befragung einer größeren Anzahl von 70 aktiven Kunst- und Turmspringern ließ eine Häufung mehr oder weniger starker Rückenschmerzen im Lumbalbereich erkennen. Diese Beschwerden wurden insbesondere in der Gruppe derjenigen angegeben, die ihren Sport bereits über längere Zeit, mindestens über fünf Jahre ausübten. Es wurden bei der Befragung und Untersuchung nur Aktive berücksichtigt, die den Sport wettkampfmäßig ausübten bzw. über lange Zeit ausgeübt hatten.

Entsprechend dem über Jahre durchgeführten Training mit einer sehr hohen Anzahl von Sprüngen erschien dieses Kollektiv auch geeignet, die entsprechenden Untersuchungen durchzuführen und eventuelle bereits röntgenologisch nachweisbare Veränderungen aufzudecken.

Zur Erklärung der noch zu besprechenden Befunde ist eine Analyse des Sprunges voranzustellen. Dabei ist eine Unterteilung in Sprünge vom Turm, d.h. im allgemeinen 
von der $10 \mathrm{~m}$-Plattform und solche vom Brett, d.h. aus der Höhe von $1-3 \mathrm{~m}$, erforderlich, da hierbei hinsichtlich der Druckbelastung unterschiedliche Gegebenheiten vorhanden sind.

Während beim Absprung vom Turm eine Druckbelastung der Wirbelsäule nur in sehr geringem Maße vorhanden ist, da die Plattform nicht federt, ist diese bei Absprung vom federnden Brett erheblich höher. Dieses Gegenfedern gilt allerdings nur für Trainingssprünge, da hier das Federn bzw. das Springen auf dem Brett häufig und mit großer Intensität geübt wird. Hierbei muß aber berücksichtigt werden, daß diese Druckbeanspruchung zu einem Teil durch die Sprung-, Knie- und Hüftgelenke abgefangen wird. Weiterhin ist dieser Belastung noch aus einem zweiten Grund nur eine untergeordnete Bedeutung beizumessen. Wie Versuche von Krayenbühl, Wyss und Ulrich am Präparat ergeben haben, ist die Druckbelastungsfähigkeit der Lendenwirbelsäule in der Längsrichtung so erheblich, daß bei einer Belastung der letzten Lendenbandscheibe von $500 \mathrm{~kg} / \mathrm{mm}^{2}$ noch kein Bruch der Zwischenwirbelscheibe eintritt. Daß hier primär gesunde Lendenwirbelsäulen vorhanden sind, muß dabei als Grundlage vorausgesetzt werden, da alle Untersuchten den Sport in frühester Jugend, z.T. schon im ersten Lebensjahrzehnt, begonnen haben.

Die zweite Phase des Sprunges spielt sich in der Luft ab, wobei der Körper um die verschiedenen Achsen im allgemeinen mehrfach gedreht wird. Da in dieser Phase lediglich eine rein funktionelle Belastung in Form von Bewegungen vorliegt, dürften hiervon keinerlei Schädigungen zu erwarten sein.

Der dritten Phase, d.h. dem Eintauchen in das Wasser, kommt m.E. nach hinsichtlich eventueller Schädigungen die größte Bedeutung $z u$, da es hier durch das Eintauchen in das andere Element zu ruckartigen Verbiegungen der Wirbelsäule kommen kann. Ein gut gelungener Sprung dürfte dabei in Bezug auf derartige Mikrotraumen ohne Bedeutung sein, da hier der Körper senkrecht mit den Händen, den Armen, dem Kopf und den Schultern eintaucht. Wir selbst erleben im allgemeinen, d.h. bei Wettkämpfen, selbstverständlich mehr gelungene als nicht gelungene Sprünge. Wie oft muß aber ein Springer einen derartigen schwierigen Sprung trainiert haben, um ihn bis zur fast völligen Vollendung $\mathrm{zu}$ beherrschen. Diese Trainingssprünge aber bzw. das Eintachen nach solchen mißlungenen Sprüngen schaffen eine Biegungsbelastung der Wirbelsäule meistens im Hyperextensions-, gelegentlich aber auch im Hyperflexion sinne.

Dabei fällt auf, daß Springer häufig über Lendenwirbelsäulenschmerzen nach derartigen mißglückten Sprüngen klagen. Eine genaue klinische Untersuchung ergibt dann in vielen Fällen einen ganz umschriebenen Druckschmerz der Dornfortsatzspitzen zweier benachbarter Wirbelkörper. Es kommt hier also durch den Hyperextensionsmechanismus zu unphysiologischen Berührungen der Dornfortsatzspitzen untereinander. Entsprechend kann man annehmen, daß auch die übrigen Teile der Bewegungssegmente einer deratigen unphysiologischen Biegungsbelastung ausgesetzt werden.

Selbstverständlich ist eine derartige einmalige oder auch mehrmalige Belastung in Sinne eines Mikrotraumas keinesfalls geeignet, Veränderungen erheblichen Ausmaßes an den betroffenen Abschnitten der Wirbelsäule hervorzurufen. Die Belastung liegt vielmehr in der ständigen Wiederholung derartiger Mikrotraumen bei einer durchschnittlichen Sprungfrequenz von 14000 Sprüngen pro Jahr.

Es muß sowohl hinsichlich der klinischen als auch der röntgenologischen Befunde eine klare Differenzierung in zwei Gruppen durchgeführt werden:

1 Die Gruppe der Jugendlichen, in unserem Falle 25, deren Trainingsdauer die Fünfjahresgrenze, die relativ willkürlich gesetzt wurde, nicht überschreitet, und

2 die Gruppe derjenigen, deren Training sich über fünf und mehr Jahre erstreckt, in unserem Falle 45 klinisch und röntgenologisch untersuchte Sportler.

Bewußt wurde bei dieser Einteilung die Grenze nicht in Altersgruppen gezogen, da der Beginn des intensiven Trainings sich immer mehr verschiebt und heute bereits z.T. im ersten Lebensjahrzehnt liegt.

Weiterhin konnte leider eine geplante Einteilung nicht durchgeführt werden, nämlich die zwischen Turm- und Brettspringern, da Springer, die fast nur oder ausschließlich vom Turm trainieren, nicht unter den Untersuchten waren und somit eine Aussage hierzu nicht zu machen gewesen wäre.

Die Befragung der Aktiven ergab hinsichtlich der Beschwerden insofern recht aufschlußreiche Befunde, als in der Gruppe 1, also der Gruppe, deren Trainingsdauer unterhalb der Fünfjahresgrenze liegt, nur in 3 Fällen Beschwerden angegeben wurden. Dagegen lag die Beschwerdehäufigkeit in Form mehr oder weniger ständiger Rückenschmerzen im Lumbalbereich in der Gruppe 2 bei 77\%. Über ischialgiforme Beschwerden wurde nur vereinzelt geklagt und dann auch nur während kürzerer Zeitabschnitte. Echte Ischialgien mit radikulären Zeichen auch über kürzere Zeit wurden in 2 Fällen angegeben. Es fanden sich bei den klinischen Untersuchungen allerdings keine echten Zeichen einer Wurzelirritation.

Bei der Untersuchung wurde in typischer Weise die 
Form und die Beweglichkeit der Wirbelsäule untersucht und weiterhin der Zustand der Rücken- und Bauchmuskulatur beurteilt.

In der Gruppe 1 bestanden zwar in einigen Fällen Zeichen einer leichten Haltungsschwäche bei relativ mäßig ausgebildeter Muskulatur, echte Einschränkungen der Beweglichkeit wurden aber nicht gefuriden. In der Gruppe 2 fand sich in 16 Fällen, d.h. in rund 35\%, eine erhebliche Steilstellıng der Lendenwirbelsäule, deren Deutung zweierlei Ursachen zuläßt:

a Es handelt sich hierbei um die von Güntz beschriebene reflektorische Steilstellung der Lendenwirbelsäule bei Beschwerden im Lumbalbereich oder

b diese Steilstellung ist eine Anpassungshaltung an die Stauchungsbelastung der Wirbelsäule beim Absprung bzw. bei den Sprungübungen auf dem Brett, da die Stauchungsbelastungsfähigkeit der Wirbelsäule in der Längsachse am größten ist und dementsprechend die steilgestellte Wirbelsäule die geringste Belastung erfährt.

Die Prüfung der Beweglichkeit insbesondere der Lendenwirbelsäule ergab in der Gruppe 1 keinen wesentlichen von der Norm abweichenden Befund, während in der Gruppe 2 eine auffällige Einschränkung der Inklination im 26 Fällen, also in ca. 58\%, vorlag. Gleichfalls fand sich eine Einschränkung der Reklination besonders am dorso-lumbalen Übergang bei 20 der Untersuchten, also in ca. $44 \%$.

Auch hierfür fällt eine Erklärung nicht leicht. Es könnte sich dabei um mit der Zeit zunehmende Veränderungen des ständig gezerrten Kapsel-Bandapparates mit Schrumpfungsvorgängen und dadurch bedingte Einschränkung der Beweglichkeit handeln.

Röntgenologisch waren die auffälligsten Befunde zu erheben: Es wurden die klinischen Befunde hinsichtlich der Beweglichkeit der Lendenwirbelsäule bestätigt, und es bestanden bei 22 der Untersuchten der Gruppe 2 erhebliche Arthrosen der Dornfortsatzspitzen im Sinne von kissing spines. Erklärt werden können diese Veränderungen mit dem oben beschriebenen Vorgang der Hyperextension und den beobachteten beschriebenen Beschwerden der Durnfortsatzspitzen nach derartigen Hyperextensionsmechanismen. Es fanden sich weiterhin auf den Schrägaufnahmen bei 35 der 45 röntgenologisch Untersuchten echte Arthrosen der kleinen Wirbelgelenke, ohne daß die sonstigen typischen Zeichen einer Spondylarthrose in Form von Osteochondrose und Spondylose vorlagen.

Erklärlich sind diese Veränderungen durch die sicher erheblichen Beeinflussungen der kleinen Wirbelgelenke ohne gleichzeitige Beeinträchtigung der Zwischenwirbelkörpergrund- und -deckplatten bzw. der Zwischenwirbelscheiben. Der typische Entstehungsmechanismus der Spondylarthrose setzt im allgemeinen eine vorausgehende Chondrose, Osteochondrose und Spondylose voraus, als deren Folge eine Gefügelockerung mit Irritation der kleinen Wirbelgelenke auftritt.

Der für uns auffälligste Befund in Form von Spondylolysen bzw. Spondylolisthesen lag in der Gruppe 1 in keinem Fall vor, während derartige Befunde in der Gruppe 2 in 9 Fällen beobachtet würden. Hierzu kommen noch vier Schrägaufnahmen der Lendenwirbelsäule, die eine deutliche Strukturunruhe im Halsbereich von L 5 erkennen ließen, ohne daß man sich dabei bereits zu der Diagnose einer echten Spondylolyse entschließen konnte.

Vergleicht man hierzu die in der Literatur $\varnothing \overrightarrow{0}$ angegebenen Zahlen hinsichtlich der Spondylolysehäufigkeit der Durchschnittsbevölkerung mit $5 \%$, so liegt die Spondylolysehäufigkeit bei Kunst- ? und Turmspringern mit $20 \%$ weit über diesem angegebenen Durchschnitt und regt selbstverständlich zur Diskussion über die Entstehung der Spondylolyse an.

Die von Barraud, Friberg, Neugebauer, Pfahler u.a. vertretene Auffassung der kongenitalen Entstehung einer Spondylolyse kann in dem hier vorliegenden Fall keine Anwendung finden. Dagegen könnte hier die Theorie von Anderson, Hadley, Lehn, Nathan und Törner über die trophostatische Entstehung des Isthmusspaltes herangezogen werden, wobei die Autoren der Meinung sind, daß eine schleichende Fraktur als Folge von Überlastungsschäden im Sinne von Umbauzonen des Zwischenwirbelgelenkes vorliegt. Auch die von Jaeger, u.a. vertretene Theorie der Ernährungsstörung des Isthmus durch Kompression der Arteria nutricia des Isthmus wäre in diesem Falle anwendbar.

Zum Abschluß möchte ich Ihnen noch eine Besonderheit zeigen, es handelt sich hierbei um eine Lösung der Spitze eines Gelenkfortsatzes, ebenfalls bei einem Kunst- und Turmspringer. 


\section{ABSTRACTS OF THREE PAPERS}

V. ILIESCU, M.D. and N. STANESCU, M.D.

Centrul de Medicina Sportiva, Bukarest, Romania

\section{PISIFORM ARTHRITIS IN GYMNASTS}

An account is given of the pathogenesis of pisiform arthritis in gymnasts with management of the condition both clincially and by mechanical alterations to gymnastic technique.

\section{SPONDYLOLYSIS AND SPONDYLOLISTHESIS IN TOP SPORTSMEN}

\section{$\mid B I D$}

The authors discuss the aetiology of this condition, suggesting congenital and over-use factors. A series of 12 cases in top athletes over the past four years is presented, with conclusions as to management, especially in respect of sports participation.

\section{DIAGNOSIS OF STRESS AND OVERTRAINING STATES IN TOP ATHLETES}

\section{N. STANESCU, M.D.}

The author presents a classification of the stress states in highly trained athletes. These relate more to the physiological stresses of training than to traumatic events. A diagnostic complex is suggested:-

Basic pathology as found in laboratory studies of stressed tissues.

Clinical diagnosis by site affected, symptomatically

Evolution of the lesion with clinical implications

and Relation to training state with therapeutic implications.

(This paper has already been published in full in Brit. Journ. Sports Med., Vol. V, No. 2, Sept. $1970 . \quad$ Ed. B.J.S.M.)

\section{TRAUMATIC BURSITIS IN A BOXER'S HAND}

P. N. SPERRYN, M.R.C.P., D.Phys.Med.

Athletes' Clinic, King's College Hospital, London

lllustration is given by contrast radiography of a traumatic bursa over the third metacarpophalangeal joint of a boxer's hand.

Present address: Phys. Med. Dept., Hillingdon Hospital, Middlesex. 